\title{
Synthesis and Biological Evaluation of 2-Acyl Analogues of Paclitaxel (Taxol)
}

David G. I. Kingston,* Ashok G. Chaudhary, Mahendra D. Chordia, Milind Gharpure, A. A. Leslie Gunatilaka, Paul I. Higgs, J ohn M. Rimoldi, Lakshman Samala, and Prakash G. J agtap

Department of Chemistry, Virginia Polytechnic Institute and State University, Blacksburg, Virginia 24061-0212

Paraskevi Giannakakou

Medicine Branch, Division of Clinical Sciences, National Cancer Institute, National Institutes of Health, Bethesda, Maryland 20892

Yuan Q. J iang, Chii M. Lin, and Ernest Hamel

Laboratory of Drug Discovery Research and Development, Developmental Therapeutics Program, Division of Cancer Treatment and Diagnosis, National Cancer Institute, Frederick Cancer Research and Development Center, Frederick, Maryland 21702

Byron H. Long, Craig R. Fairchild, and Kathy A. J ohnston

Bristol-Myers Squibb Pharmaceutical Research Institute, P.O. Box 4000, Princeton, New J ersey 05843

Received April 13, 1998

The anticancer drug paditaxel (Taxol) has been converted to a large number of 2-debenzoyl2 -aroyl derivatives by three different methods. The bioactivities of the resulting analogues were determined in both tubulin polymerization and cytotoxicity assays, and several analogues with enhanced activity as compared with paclitaxel were discovered. Correlation of cytotoxicity in three cell lines with tubulin polymerization activity showed reasonable agreement. Among the cell lines examined, the closest correlation with antitubulin activity was observed with a human ovarian carcinoma cell line.

\section{Introduction}

Interest in the novel diterpenoid paclitaxel (Taxol) (1) continues at a high level from chemical, biological, and clinical viewpoints. First isolated in low yield in the late 1960s from the bark of the western yew, Taxus brevifolia, ${ }^{1}$ paclitaxel was not initially considered a viable clinical candidate because of concerns about its supply and its lack of aqueous solubility. Encouragingly positive results in new in vivo models in the mid-1970s spurred reconsideration of its potential, and paclitaxel entered preclinical studies in the late 1970s. The discovery of its novel mechanism of action, involving enhancement of the polymerization of tubulin and formation of stable microtubule polymers, ${ }^{2}$ greatly increased interest in the compound. Clinical trials ultimately demonstrated its clinical effectiveness, and paclitaxel is now approved for treatment of ovarian and breast cancers, with promise al so for treatment of lung, skin, and head and neck cancers. ${ }^{3}$
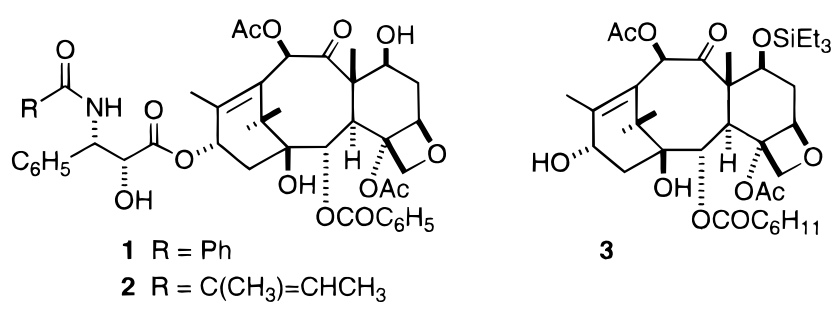

A large number of structure-activity relationship (SAR) studies of paclitaxel have been carried out, particularly in recent years, and have led to the general conclusions that the $\mathrm{C}-13$ ester side chain is essential for activity, that modifications to the "northern hemisphere" (C-7, C-9, and C-10) have modest but often beneficial effects on its bioactivity, and that changes to the "southern hemisphere" (C-4, C-2, and the oxetane ring) can have larger effects on activity, usually negative but occasionally positive. ${ }^{4}$ Thus opening of the oxetane ring leads to loss of activity, ${ }^{5}$ as does deacetylation or deacetoxylation at C-4. ${ }^{6}$ Replacement of the C-4 acetate with other acyl groups, however, results in restoration or even enhancement of activity. ${ }^{7}$

The C-2 benzoate has only recently been explored as a target for SAR studies of paclitaxel. Following our initial report of the enhanced activity of certain C-2 aroyl paclitaxels, ${ }^{8}$ reports confirming and extending this result have appeared from other laboratories. ${ }^{9}$ The importance of the $\mathrm{C}-2$ substituent has been highlighted by studies that connect the bioactivity of paclitaxel with a "hydrophobic collapse" of the side chain with the C-2 benzoate and the C-4 acetate substituents. ${ }^{10}$ In this paper we report further examples of C-2 aroyl-substituted paclitaxels, and we provide both tubulin assembly and cytotoxicity data for all compounds.

\section{Chemistry}

Studies on the preparation of 2-aroyl analogues of paclitaxel were hampered initially by the difficulty of removing the 2-benzoyl group selectively. Thus, treatment of cephalomannine (2), a close analogue of paclitaxel, with methanolic base led only to cleavage of the side chain or of the 10-acetate or both, ${ }^{11}$ while treatment of 7-O-(triethylsilyl)hexahydrobaccatin III (3) under 


\section{Scheme $1^{a}$}

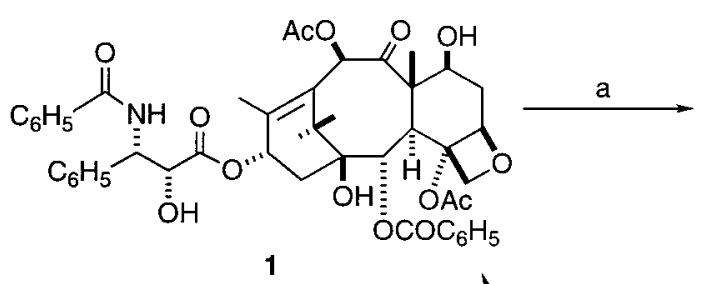<smiles>CCCCCCCCCCCCO</smiles>

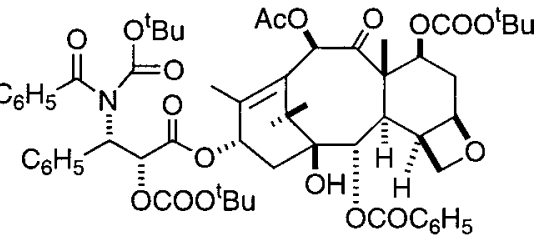<smiles></smiles>

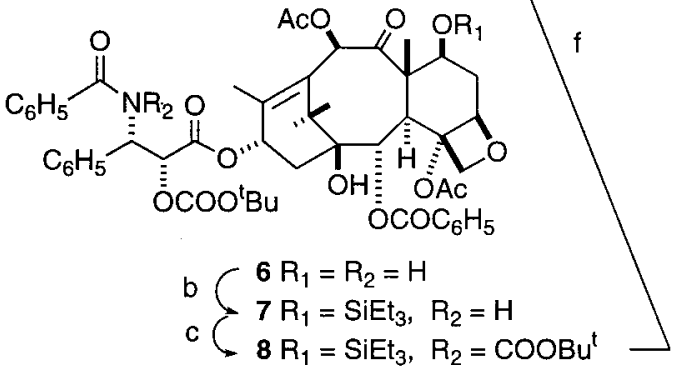

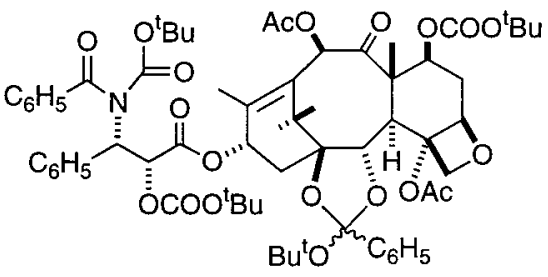

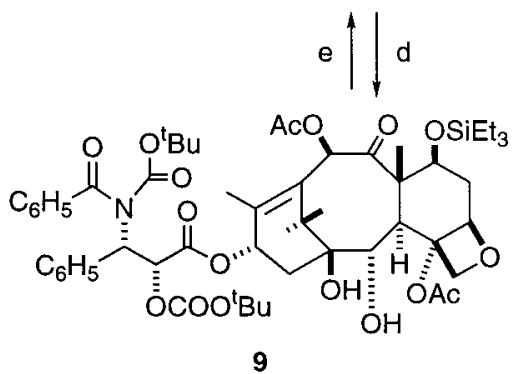

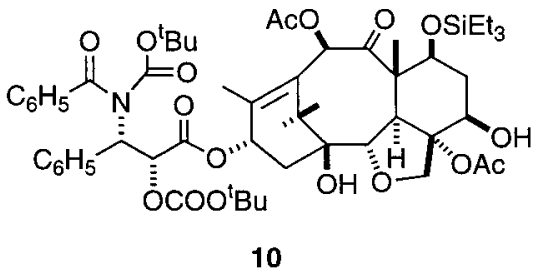

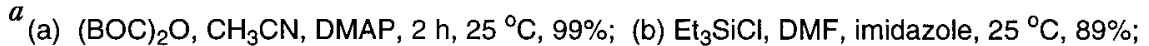

(c) (BOC) ${ }_{2} \mathrm{O}, \mathrm{CH}_{3} \mathrm{CN}$, DMAP, $3 \mathrm{~h}, 25^{\circ} \mathrm{C}, 88 \%$; (d) $0.1 \mathrm{~N} \mathrm{LiOH}, \mathrm{THF}, 2 \mathrm{~h}, 0^{\circ} \rightarrow 25^{\circ} \mathrm{C}, 76 \%$;

(e) $\mathrm{PhCOOH}, \mathrm{DCC}, \mathrm{PP}, \mathrm{PhCH}_{3}, 8 \mathrm{~h}, 50^{\circ} \mathrm{C}, 68 \%$; (f) $\mathrm{HCl} / \mathrm{HCOOH}, 30 \mathrm{~min}, 25^{\circ} \mathrm{C}, 28 \%$.

similar conditions gave hydrolysis in the order 10acetate $>4$-acetate $>$ 2-benzoate. ${ }^{12}$ Debenzoylations of 7,13-di-O-(triethylsilyl)baccatin III and 7-O-(triethylsi|yl)-10-deacetyl baccatin III have been reported, ${ }^{12}$ but the yields of 2-debenzoyl product were low, and the reactions were unsuited to development of a general synthesis.

In seeking to address this need for a general approach to the preparation of 2-debenzoylpaclitaxel, we investigated the use of various nonaqueous reagents and conditions. Although the initial discovery of the effectiveness of such conditions was empirical, their use can be understood on the basis of recent NMR and molecular modeling studies, which indicate that paclitaxel adopts a compact globular form in aqueous media but a more open conformation in chloroform. ${ }^{10}$ It seems probable that this more open conformation allows nucleophilic attack to occur more readily at the C-2 benzoate. Three different routes were developed for the C-2 debenzoylation of paclitaxel, and each will be described briefly in turn.

The tert-Butoxycarbonyl Route. Our interest in the development of selective methods for $\mathrm{N}$-debenzoylation of paclitaxel or its congener cephalomannine led us to react paclitaxel with di-tert-butoxy dicarbonate under various conditions, in an attempt to form $2^{\prime}-0,7-$ $\mathrm{O}, 3^{\prime}$-N-tri(tert-butoxycarbonyl)paclitaxel (4). Formation of this compound required forcing conditions and was always accompanied by formation of some of the ortho ester derivative 5. Although the ortho ester $\mathbf{5}$ could be converted to the desired tri(tert-butoxycarbonyl) derivative under mild conditions, we desired an alternative procedure. Since the overreaction appeared to be due to the forcing conditions necessary to acylate at the 7-position, we adopted the expedient of first preparing 2'-O-(tert-butoxycarbonyl)paclitaxel (6) and converting it to its 7-O-(triethylsilyl) derivative 7 (Scheme 1). Compound 7 could be converted in good yield into 2'O,3'-N-di (tert-butoxycarbonyl)-7-O-(triethylsilyl)paclitaxel (8).

Selective deacylation of si mple N-tert-butoxycarbonyl$\mathrm{N}$-acylimides normally occurs under basic conditions to give N-deacyl-N-tert-butoxycarbonyl derivatives. ${ }^{13}$ However, treatment of $\mathbf{8}$ with various bases unexpectedly failed to give any $\mathrm{N}$-debenzoyl product, instead yiel ding a mixture of the 2-debenzoyl product $\mathbf{9}$ and the rearranged debenzoyl product 10. ${ }^{14}$ Under some conditions the undesired tetrahydrofuran $\mathbf{1 0}$ was the major product, but careful control of conditions enabled us to prepare 9 in reasonable yield (76\%) from $\mathbf{8}$.

The availability of $\mathbf{9}$ enabled us to investigate reacylation conditions. The use of carboxylic acid in the presence of dicyclohexylcarbodiimide (DCC) and 4-pyrrolidinopyridine (PP) proved to be the most effective method. The conditions required careful control, since under uncontrolled conditions rearrangement to $\mathbf{1 0}$ 


\title{
Scheme $2^{a}$
}

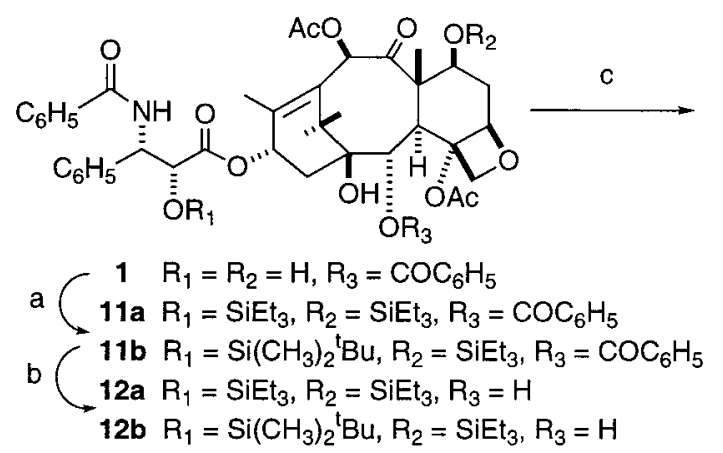

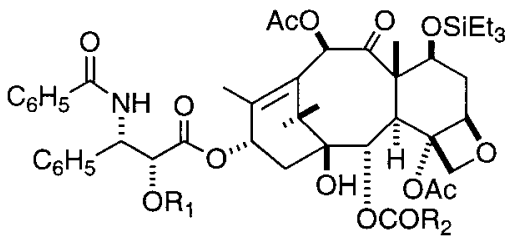

13a $R_{1}=$ SiEt $_{3}, R_{2}=$ various aryl substituents

13b $R_{1}=\mathrm{Si}\left(\mathrm{CH}_{3}\right)_{2}{ }^{\mathrm{t}} \mathrm{Bu}, \mathrm{R}_{2}=$ various aryl substituents

$\mathrm{d}$

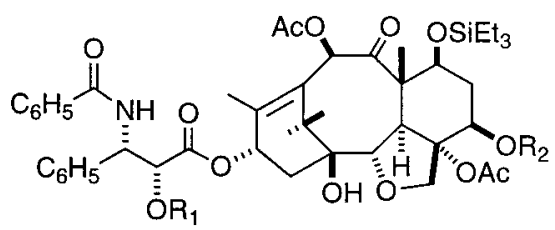

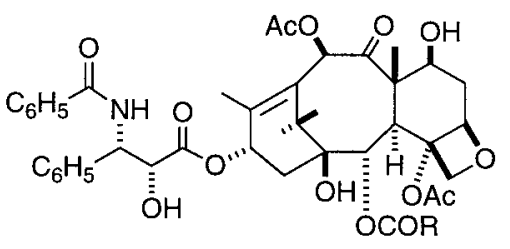

15a $\quad R_{1}=\operatorname{SiEt}_{3}, R_{2}=H$

15b $\mathrm{R}_{1}=\mathrm{Si}\left(\mathrm{CH}_{3}\right)_{2}{ }^{\mathrm{t}} \mathrm{Bu}, \mathrm{R}_{2}=\mathrm{H}$

16a $\quad \mathrm{R}_{1}=\mathrm{SiEt}_{3}, \mathrm{R}_{2}=\mathrm{COAr}$

16b $\quad \mathrm{R}_{1}=\mathrm{Si}\left(\mathrm{CH}_{3}\right)_{2}{ }^{t} \mathrm{Bu}, \mathrm{R}_{2}=\mathrm{COAr}$

14aa-eg $R=$ various aryl substituents

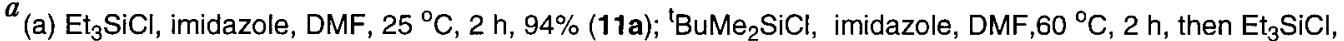
imidazole, DMF, $25^{\circ} \mathrm{C}, 1 \mathrm{~h}, 95 \%(11 \mathrm{~b})$; (b) $11 \mathrm{a}, \mathrm{C}_{6} \mathrm{H}_{6} / \mathrm{CH}_{2} \mathrm{Cl}_{2}, \mathrm{Bu}_{4} \mathrm{NHSO}_{4}, 2 \mathrm{~N} \mathrm{NaOH}, 25^{\circ} \mathrm{C}, 2 \mathrm{~h}, 72 \%$ (12a); 11b, $\mathrm{CH}_{2} \mathrm{Cl}_{2}, \mathrm{PhCH}_{2} \mathrm{NMe}_{3} \mathrm{OH},-78^{\circ} \mathrm{C}>-10^{\circ} \mathrm{C}, 15 \mathrm{~min}, 81 \%$ (12b); (c) $\mathrm{RCOOH}, \mathrm{PhCH}_{3}, \mathrm{DCC}, \mathrm{PP}$, 4 - $16 \mathrm{~h}, 60-90 \%$; .(d) $\mathrm{HCl} / \mathrm{MeOH}, 25^{\circ} \mathrm{C}, 45-60 \mathrm{~min}, 70-90 \%$.
\end{abstract}

occurred. Under controlled conditions, however, the protected paclitaxel $\mathbf{8}$ could be prepared by benzoylation of 9. Deprotection of $\mathbf{8}$ with $\mathrm{HCl} / \mathrm{HCOOH}$ yielded paclitaxel (1), thus indicating that no untoward rearrangements had occurred. The yield in the deprotection step was poor, however, and since attempts to improve it proved unrewarding, we sought a better route.

The Phase-Transfer Catalysis R oute. The second route made use of phase-transfer catalysis, which allows the use of water-soluble bases while maintaining the substrate in a nonaqueous environment. As indicated above, such conditions might be expected to facilitate selective hydrolysis of the 2-benzoate by allowing the molecule to "open up" in the absence of hydroxylic solvents. Various solvents, bases, and phase-transfer catalysts (PTCS) were investigated, and eventually the combination of benzene/dichloromethane (8:2) as organic solvent, tetrabutylammonium chloride as the PTC, and $2 \mathrm{~N} \mathrm{NaOH}$ as the base was selected as providing the best combination of selectivity and reactivity. Under these conditions 2',7-di-O-(triethyl silyl)pad itaxel (11a) was an acceptable substrate, and it was converted to 2-debenzoyl-2',7-di-O-(triethylsilyl)paclitaxel (12a) in reasonable yield $(72 \%)$ if the reaction was stopped at approximately 50\% conversion (Scheme 2). If reaction was pushed beyond $50 \%$ conversion, the rearranged derivative 15a was formed in increasing amounts, and the overall yield of the desired product declined.

Reacylation of $\mathbf{1 2 a}$ with various carboxylic acids in the presence of DCC and PP gave protected 2-acylpaclitaxel analogues of general structure 13a. The yield of isolated product was acceptable (60-90\%, depending on the acid), provided that a large excess of the acid component was used. Deprotection with $\mathrm{HCl} / \mathrm{MeOH}$ gave the analogues 14aa-eg (see Table 1). Overall yields from paclitaxel by this route ranged from $27 \%$ to $52 \%$, depending primarily on the difficulty of the reacylation step (12a $\rightarrow$ 13a). The major byproduct in the deacylation and reacylation steps was the rearranged paclitaxel $\mathbf{1 5 a}$ or its acylation product $\mathbf{1 6 a}$.

The Triton B Route. Although the phase-transfer catalytic route provided acceptable yields of product, the debenzoylation step was a difficult one requiring careful monitoring of the reaction mixture and careful judgement of when to stop the reaction. We thus sought an improved method for this step. Reasoning that the use of a bulky protecting group at the 2'-position would reduce undesired hydrolysis of the $\mathrm{C}-13$ ester side chain, we elected to use a 2'-O-tert-butyl dimethylsilyl protecting group. The 7-position was then protected with an O-triethylsilyl protecting group in the usual way. The protected derivative $\mathbf{1 1 b}$ could be conveniently prepared in $95 \%$ yield in a one-pot reaction. After trials of several different sets of reagents and conditions, we found that the lipophilic base Triton B (benzyltrimethylammonium hydroxide in methanol) provided a convenient and highyield method to prepare the 2-debenzoyl anal ogue $\mathbf{1 2 b}$. Thus treatment of $\mathbf{1 1 b}$ with Triton $B$ in dichloromethane at $-78^{\circ} \mathrm{C}$ with subsequent warming to -10 ${ }^{\circ} \mathrm{C}$ gave the desired debenzoyl analogue $\mathbf{1 2 b}$ in $73 \%$ yield, or in $81 \%$ yield based on unreacted starting material. Although this procedure al so requires careful monitoring, it is somewhat simpler experimentally than the phase-transfer method and is now our method of choice for this reaction. Reacylation of $\mathbf{1 2 b}$ and deprotection of the product $\mathbf{1 3} \mathbf{b}$ to the paclitaxel analogues 14aa-eg proceeded smoothly as described above, and this method, besides being simpler experimentally, gave somewhat improved overall yields of $32-62 \%$, again depending primarily on the acid used. The major 
Table 1. 2-Acylpaclitaxel Analogues Prepared

\begin{tabular}{|c|c|c|c|c|c|}
\hline compd & $\begin{array}{l}\text { phenyl ring } \\
\text { substituent }\end{array}$ & compd & $\begin{array}{c}\text { phenyl ring } \\
\text { substituent(s) }\end{array}$ & compd & $\begin{array}{c}\text { phenyl ring } \\
\text { substituent(s) (14df- }-\mathbf{d n}) \text { or } \\
\text { 2-substituent }(\mathbf{1 4 e a}-\mathbf{e g})\end{array}$ \\
\hline $14 a a$ & 2-OMe & 14bn & $3-\mathrm{Br}$ & 14df & $3,4,5-\mathrm{OMe}$ \\
\hline $14 a b$ & $2-\mathrm{F}$ & $14 \mathrm{bo}$ & $3-\mathrm{CF}_{3}$ & 14dg & 3,5-OMe \\
\hline $14 a c$ & $2-\mathrm{Cl}$ & 14bp & $3-\mathrm{CN}^{3}$ & $14 d h$ & $3,4-\mathrm{F}$ \\
\hline 14ad & $2-\mathrm{N}_{3}$ & $14 \mathrm{bq}$ & $3-\mathrm{NO}_{2}$ & 14di & $3,5-\mathrm{N}_{3}$ \\
\hline 14ba & 3-OEt & $14 c a$ & $4-\mathrm{OH}$ & 14dj & $3,4-\mathrm{Cl}$ \\
\hline $14 \mathrm{bb}$ & 3-OPr & $14 c b$ & 4-OMe & 14dk & $3,5-F$ \\
\hline $14 \mathrm{bc}$ & 3-OiPr & $14 c c$ & $4-\mathrm{OCH}_{2} \mathrm{Ph}$ & 14dl & $3,4,5-F$ \\
\hline $14 \mathrm{bd}$ & $3-\mathrm{OCH}_{2} \mathrm{Ph}$ & $14 c d$ & $4-\mathrm{F}$ & $14 \mathrm{dm}$ & $3,5-\mathrm{Cl}$ \\
\hline 14be & $3-\mathrm{OH}$ & $14 c e$ & $4-\mathrm{N}_{3}$ & 14dn & $3,5-\mathrm{NO}_{2}$ \\
\hline 14bf & 3-OMe & 14cf & $4-\mathrm{Cl}$ & 14ea & 2-thiophenecarbonyl \\
\hline $14 \mathrm{bg}$ & 3-SMe & $14 \mathrm{cg}$ & $4-\mathrm{CN}$ & 14 eb & 3-thiophenecarbonyl \\
\hline $14 \mathrm{bh}$ & 3-OPh & $14 \mathrm{ch}$ & $4-\mathrm{NO}_{2}$ & 14 ec & 2-furoyl \\
\hline 14bi & $3-N_{3}$ & 14da & $2,3-\mathrm{F}$ & 14ed & 3-furoyl \\
\hline 14bj & $3-F$ & 14db & $2,5-\mathrm{F}$ & 14ee & phenoxyacetyl \\
\hline 14bk & $3-1$ & 14dc & $2,4,5-\mathrm{F}$ & 14 ef & acetyl \\
\hline 14bl & $3-\mathrm{Cl}$ & 14dd & 2,3-OMe & 14 eg & valeryl \\
\hline 14bm & 3-COMe & 14de & $2,5-\mathrm{OMe}$ & & \\
\hline
\end{tabular}

\section{Scheme 3}

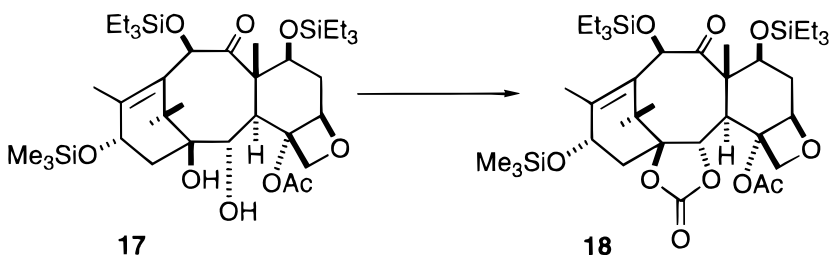

Scheme 4

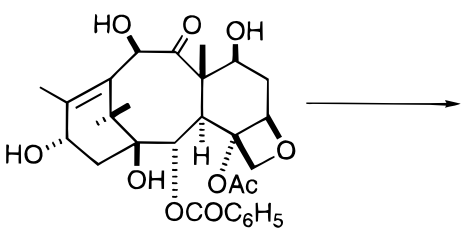

19

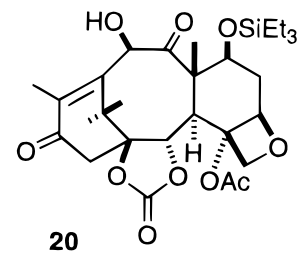

byproduct in the deacylation and reacylation steps was again the rearranged paclitaxel $\mathbf{1 5 b}$ or its acylation product $\mathbf{1 6 b}$.

Discussion. It is interesting to compare the relative advantages and disadvantages of the various routes that have now been reported for the preparation of 2-acyl2-debenzoylpaclitaxels. Four approaches have been proposed, involving either paclitaxel or baccatin III as the starting material and proceeding either through a cyclic carbonate intermediate or by direct acylation at $\mathrm{C}-2$. One of the first methods was developed by Holton and proceeds from 10-deacetylbaccatin III to the cyclic 1,2-carbonate derivative $\mathbf{1 8}$ and thence to a 2-aroylbaccatin III analogue (Scheme 3). ${ }^{9 \mathrm{~h}}$ Thus protection of 10deacetyl baccatin III as its 7,10-di-O-(triethylsilyl)-13O-(trimethylsilyl) derivative followed by debenzoylation at C-2 by treatment with Red-Al gave the 2-debenzoyl analogue 17. Reaction of $\mathbf{1 7}$ with phosgene and pyridine gave the cyclic carbonate 18, and treatment of $\mathbf{1 8}$ with an aryllithium reagent gave a protected 2-debenzoyl-2aroylbaccatin III analogue. Conversion of this analogue to a corresponding paclitaxel analogue could then be accomplished by appropriate manipulations to attach the $\mathrm{C}-13$ ester side chain. ${ }^{15}$

The cyclic carbonate approach of Nicolaou'd (Scheme 4) is similar in many ways to Holton's approach. It proceeds from 10-deacetylbaccatin III (19) through the
Scheme 5

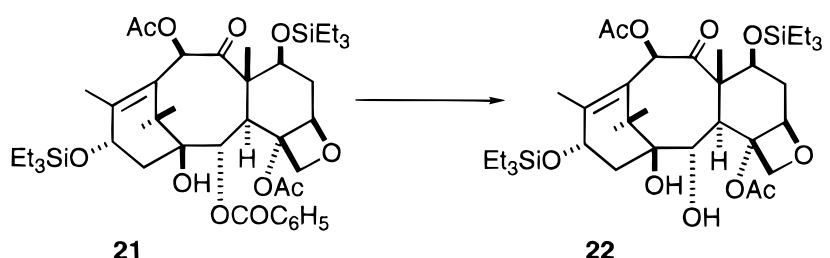

Scheme 6

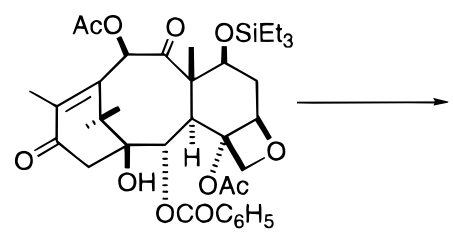

23

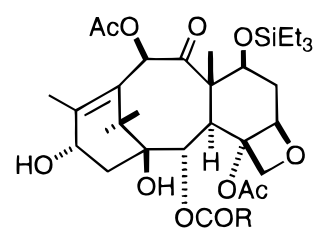

24 cyclic carbonate 20, which is formed in about $60 \%$ overall yield from 19 as a key intermediate (Scheme 4). The synthesis is somewhat lengthy, requiring four steps from $\mathbf{1 9}$ to $\mathbf{2 0}$ and six steps from $\mathbf{2 0}$ to a 2-acyl paclitaxel. The combined yields of these latter steps range from $3 \%$ to $25 \%$, giving an overall yield for the route of $2-15 \%$, depending on the acyl group.

A pathway that combines the direct acylation chemistry of our method with a baccatin III starting material was developed by Chen et al. ${ }^{\text {9e }}$ (Scheme 5$)$. This route proceeds via 7,13-di-O-(triethylsilyl)baccatin III (21), which is debenzoylated with Red-Al to the 2-debenzoyl derivative 22. Reacylation of this intermediate followed by side-chain attachment gives 2-acylpaclitaxel analogues in overall yields of $15-27 \%$, depending on the acid used. This method is thus somewhat more direct than Nicolaou's approach, while retaining the advantages associated with a baccatin III starting material. A similar pathway from 10-deacetyl baccatin III was also developed by Holton. ${ }^{\text {h }}$ A final pathway from a baccatin III starting material was developed by $\mathrm{Chen}^{9 \mathrm{e}}$ and improved by Ojima. ${ }^{9 i}$ It involves the deacylation of the 13-oxobaccatin III derivative $\mathbf{2 3}$ (Scheme 6) and subsequent reacylation and reduction to give the baccatin III anal ogue 24.

Finally, Georg's method ${ }^{9 b}$ is very similar to the Triton $B$ route described here. It uses a different base and 
slightly different reacylation conditions, but it is very comparable in terms of yield and convenience.

Each of the methods described has its own advantages and limitations. The methods of Holton, Nicolaou, and Chen, starting as they do from baccatin III or 10deacetyl baccatin III, provide a route for the synthesis of paclitaxel analogues modified both at C-2 and on the side chain and are thus the most versatile methods in principle. The methods involving aryllithium addition to a cyclic carbonate are, however, limited to the preparation of analogues carrying substituents that are compatible with the aryllithium functionality and cannot be used to prepare derivatives with nitro, cyano, azido, carbonyl, and similar groups. The routes described in this paper and by Georg are both efficient methods for the conversion of paclitaxel to various 2-debenzoyl-2-acyl analogues and are thus the method of choice for this conversion.

In summary, the chemistry described provides a convenient access to a wide range of 2-acylpaclitaxel anal ogues through a carefully optimized set of reactions. The method is versatile, since it is not limited to those acyl groups which can be formed via a stable carbanion, and it has been used successfully for the preparation of the 50 paclitaxel analogues listed in Tables 1.

\section{Biological Evaluation}

We have previously reported $8,9 f, 16$ that 2-debenzoyl2-(m-azidobenzoyl)paclitaxel (14bi) was more potent than paclitaxel in enhancing tubulin polymerization and inhibiting cell growth of the murine P388 leukemia, human HL-60 leukemia, and human Burkitt lymphoma CA46 lines and of several lines in the National Cancer Institute human cancer screen. These observations with 14bi, as well as less extensive data with several other C-2-modified compounds, ${ }^{8}$ caused us to prepare the series of compounds described here. We wished to determine the effects of different modifications in the C-2 substituent on the activity of taxoids and hoped to prepare compounds more active than 14bi. Table 2 summarizes our evaluation to date of most of the compounds whose syntheses are described here; data for compounds not discussed in the text can be found in the complete tables appearing as Supporting Information. For all comparisons, we have expressed analogue activity relative to that of paclitaxel, so that values less than 1.0 indicate activity greater than that of the parent compound and values greater than 1.0 activity less than that of the parent compound.

We specifically designed a relatively facile assay ${ }^{16}$ with purified tubulin that is selective for compounds more active than paclitaxel toward tubulin, the drug's cellular target. We chose a reaction condition $(0.4 \mathrm{M}$ glutamate, no $\mathrm{Mg}^{2+}$, room temperature incubation, no GTP) where paclitaxel yielded a relatively high "I $\mathrm{C}_{50}$ " value $(23 \pm 2 \mu \mathrm{M})^{17}$ and $\mathbf{1 4 b i}$ a low one $(4.7 \pm 0.1 \mu \mathrm{M})$. Compounds less active than paclitaxel were also evaluated in $0.8 \mathrm{M}$ glutamate, a modification that substantially enhances the activity observed with paclitaxel ${ }^{16}$ (IC ${ }_{50}$ value, $\left.4.5 \pm 0.1 \mu \mathrm{M}\right)$, while that of $\mathbf{1 4 b i}$ changes little (I Fo $_{50}$ value, $\left.2.8 \pm 0.06 \mu \mathrm{M}\right)$. Compounds with I $\mathrm{C}_{50}$ values less than $40 \mu \mathrm{M}$ in either assay were evaluated several times to confirm their activity. Based on the standard deviations obtained, a 20\% difference between compounds is significant for the data presented in columns 3 and 4 of Table 2.

In addition, most of the analogues were evaluated in a screening assay with microtubule protein at $37^{\circ} \mathrm{C}$ without GTP (column 5, Table 2). The microtubuleassociated proteins in the preparation have an enhancing effect on tubulin polymerization similar to that of the higher glutamate concentration, ${ }^{18}$ and the higher reaction temperature can further enhance taxoid effects on tubulin assembly. ${ }^{19}$

Most of the compounds in the series were also evaluated in four human cancer cell lines. The Burkitt cells were grown in suspension culture, and the cell number was quantitated. The ovarian and colon carcinoma lines were grown in monolayer cultures, and cell protein was quantitated.

In conjunction with the parental ovarian line,20 a paclitaxel-resistant line that expresses an altered cellular $\beta$-tubulin ${ }^{21}$ was evaluated. The mutant ovarian line was 21-fold more resistant to paclitaxel than the parental line. Note that the data with this line are presented relative to the resistance level obtained with paclitaxel (column 8, Table 2). Thus, full restoration of relative sensitivity with a modified taxoid would be indicated by a value of about 0.05 , and this was not observed with any compound.

Tubulin-Based Assays. There is excellent overall agreement between the more extensive evaluations with purified tubulin and the screening evaluation with microtubule protein. There were only five significant discrepancies between the two assays, and in all cases these were compounds that were found to be less active than paclitaxel in the purified tubulin assay. In the screening assay four of these compounds (14bj,bk, bq,di) were indicated to be more active than paclitaxel and one (14bo) to be nearly equivalent to the parent drug. Surveying the data overall, there is satisfactory agreement between the biochemical and cytological results (discussed below in greater detail). In only a few cases does the microtubule data appear to be more predictive than the purified tubulin data on the effects of these compounds on cell growth (compounds 14bj, $\mathbf{b k}$, bo,di). Therefore, since the purified tubulin data were obtained with the entire series of agents and verified by repeat assays, we will primarily use these data for comparisons with the cell proliferation data and structure-activity analysis.

Comparative Effects on Cell Growth. The Burkitt cells appear to be significantly less sensitive to paclitaxel than the two parental carcinoma lines, as the former had an I $\mathrm{C}_{50}$ value of $30 \mathrm{nM}$ and the latter I $\mathrm{C}_{50}$ values of about $2 \mathrm{nM}$. We have not determined whether this is due to an intrinsic difference in sensitivities or to an artifact (e.g., the different incubation times, culture methods, or parameters measured). Overall, the range of activity was much smaller with the Burkitt cells than with the other lines. Nevertheless, there was broad similarity in sensitivity to the C-2-modified analogues in most cases. Several compounds (14bf,db, de,dm) were more active than paclitaxel in all three cell lines, and others were more active in at least two lines (14ad,bi, ,bj,bl,bn,dk). Except for compound 14bj, these anal ogues were more active with tubul in as well, and $\mathbf{1 4 b j}$ was more active than paclitaxel in the micro- 
Table 2. Bioactivity Data for 2-Acylpaclitaxels Relative to That for Paclitaxela

\begin{tabular}{|c|c|c|c|c|c|c|c|c|}
\hline \multirow[b]{3}{*}{ compd } & \multirow{3}{*}{$\begin{array}{c}\text { phenyl ring } \\
\text { substituent }(\mathbf{1 4 a a}-\mathbf{d n}) \text { or } \\
\text { 2-O-substituent (14ea-eg) }\end{array}$} & \multirow{2}{*}{\multicolumn{2}{|c|}{$\begin{array}{l}\text { polym of tubulin in } \\
\text { glutamate }\left(22^{\circ} \mathrm{C}\right)\end{array}$}} & \multirow{3}{*}{$\begin{array}{c}\text { polym of } \\
\text { microtubule } \\
\text { proteinc }\left(37^{\circ} \mathrm{C}\right)\end{array}$} & \multicolumn{4}{|c|}{ cytotoxicity with human cell lines } \\
\hline & & & & & \multirow{2}{*}{$\begin{array}{c}\text { Burkitt } \\
\text { lymphomad }\end{array}$} & \multirow{2}{*}{$\begin{array}{c}\text { ovarian } \\
\text { carcinomae }\end{array}$} & \multirow{2}{*}{$\begin{array}{l}\text { rel resistance } \\
\text { of paclitaxel- } \\
\text { resistant linef }\end{array}$} & \multirow{2}{*}{$\begin{array}{c}\text { colon } \\
\text { carcinomas }\end{array}$} \\
\hline & & $0.4 \mathrm{M}$ & $0.8 \mathrm{M}$ & & & & & \\
\hline 14aa & 2-OMe & $>1.7$ & 1.2 & 1.5 & 0.67 & 1.4 & 0.95 & 1.9 \\
\hline 14ad & $2-\mathrm{N}_{3}$ & 0.38 & & 0.70 & & 0.77 & 0.67 & 0.36 \\
\hline $14 b a$ & 3-OEt & 1.4 & 1.2 & 1.1 & 1.0 & 1.7 & 0.37 & 1.6 \\
\hline $14 \mathrm{bc}$ & 3-OiPr & $>1.7$ & $>8.9$ & $>140$ & 1.3 & 15 & 0.29 & 17 \\
\hline 14bf & 3-OMe & 0.22 & & 0.50 & 0.27 & 0.095 & 0.71 & 0.35 \\
\hline $14 \mathrm{bg}$ & 3-SMe & $>1.7$ & 2.7 & & 1.0 & 3.3 & 0.52 & \\
\hline 14bi & $3-\mathrm{N}_{3}$ & 0.20 & & 0.37 & 0.17 & 0.18 & 0.27 & 1.4 \\
\hline 14bj & $3-\mathrm{F}$ & 1.2 & 2.6 & 0.70 & & 0.40 & 0.96 & 0.45 \\
\hline 14bk & $3-1$ & $>1.7$ & 3.1 & 0.79 & 2.3 & 1.6 & 0.35 & 0.85 \\
\hline $14 \mathrm{bl}$ & $3-\mathrm{Cl}$ & 0.30 & & 0.92 & 0.67 & 0.05 & 2.9 & 1.7 \\
\hline 14bn & $3-\mathrm{Br}$ & 0.24 & & 0.80 & & 0.32 & 0.42 & 0.32 \\
\hline $14 \mathrm{bo}$ & $3-\mathrm{CF}_{3}$ & $>1.7$ & 6.7 & 1.3 & 0.67 & 1.4 & $N M^{h}$ & 3.0 \\
\hline $14 \mathrm{bp}$ & $3-\mathrm{CN}$ & 0.63 & & 1.0 & & 0.32 & 1.3 & 1.1 \\
\hline $14 \mathrm{bq}$ & $3-\mathrm{NO}_{2}$ & $>1.7$ & 1.6 & 0.69 & 1.0 & 1.3 & 0.76 & 0.88 \\
\hline $14 c a$ & $4-\mathrm{OH}$ & $>1.7$ & $>8.9$ & 19 & 3.0 & 31 & NM & 52 \\
\hline 14cf & $4-\mathrm{Cl}$ & $>1.7$ & $>8.9$ & & 1.3 & 7.6 & NM & \\
\hline 14da & $2,3-F$ & $>1.7$ & $>8.9$ & 0.80 & & 14 & NM & 0.55 \\
\hline $14 \mathrm{db}$ & $2,5-\mathrm{F}$ & 0.29 & & 0.34 & 0.67 & 0.67 & 0.57 & 0.44 \\
\hline $14 d c$ & $2,4,5-\mathrm{F}$ & $>1.7$ & 3.1 & 1.5 & 1.0 & 3.1 & 0.48 & 1.9 \\
\hline 14dd & 2,3-OMe & $>1.7$ & $>8.9$ & $>270$ & $>3.3$ & $>48$ & NM & 59 \\
\hline 14de & 2,5-OMe & 0.20 & & 0.50 & 0.67 & 0.12 & 0.76 & 0.14 \\
\hline 14df & $3,4,5-\mathrm{OMe}$ & $>1.7$ & $>8.9$ & 32 & $>3.3$ & $>48$ & NM & 110 \\
\hline $14 d g$ & $3,5-\mathrm{OMe}$ & $>1.7$ & 4.7 & 2.6 & 1.0 & 3.3 & 0.57 & 5.4 \\
\hline 14dh & $3,4-F$ & $>1.7$ & 3.1 & 2.2 & 0.33 & 3.4 & 0.57 & 2.7 \\
\hline $14 d i$ & $3,5-\mathrm{N}_{3}$ & $>1.7$ & 4.0 & 0.67 & 1.0 & 1.3 & 0.40 & 1.6 \\
\hline 14dj & $3,4-\mathrm{Cl}$ & 0.41 & & 0.76 & & 1.0 & 0.27 & 0.77 \\
\hline 14dk & $3,5-\mathrm{F}$ & 0.29 & & 0.60 & & 0.12 & 1.1 & 0.36 \\
\hline 14dl & $3,4,5-F$ & $>1.7$ & 4.7 & 1.8 & 1.3 & 3.2 & 0.62 & 3.4 \\
\hline $14 \mathrm{dm}$ & $3,5-\mathrm{Cl}$ & 0.91 & & 0.44 & 0.67 & 0.38 & 0.48 & 0.51 \\
\hline $14 \mathrm{dn}$ & $3,5-\mathrm{NO}_{2}$ & $>1.7$ & $>8.9$ & 4.2 & 2.3 & 20 & NM & 3.1 \\
\hline $14 e a$ & 2-thiophenecarbonyl & $>1.7$ & 2.9 & 4.1 & 0.67 & 4.8 & NM & 4.5 \\
\hline 14eb & 3-thiophenecarbonyl & $>1.7$ & 2.0 & 1.9 & 0.33 & 4.3 & NM & 4.5 \\
\hline 14 ec & 2-furoyl & $>1.7$ & 5.1 & 26 & 2.0 & 13 & NM & 52 \\
\hline 14ed & 3-furoyl & $>1.7$ & 3.1 & 7.8 & 1.0 & 12 & NM & 18 \\
\hline
\end{tabular}

a Activity data are recorded relative to the activity of paclitaxel in the corresponding assay, so numbers less than unity correspond to analogues that are more active than paclitaxel. The complete table with data for all compounds is included as Supporting Information. $\mathrm{b}$ The analogues were evaluated as enhancers of the assembly of purified bovine brain tubulin at room temperature without GTP at the indicated concentrations of monosodium glutamate (taken from $2 \mathrm{M}$ stock solution adjusted to $\mathrm{pH} 6.6$ with $\mathrm{HCl}$ ). ${ }^{16} \mathrm{Polymer}$ was harvested by centrifugation, and the $\mathrm{IC}_{50}$ was defined as the drug concentration reducing the protein concentration of the supernatant by $50 \%$ as compared to control reaction mixtures without drug. With active compounds, the pellet becomes progressively larger as compound concentration increases. The highest drug concentration used was $40 \mu \mathrm{M}$. Compounds yielding I $\mathrm{C}_{50}$ values were evaluated in at least three independent experiments, and those with I $\mathrm{C}_{50}$ values over $40 \mu \mathrm{M}$ were evaluated at least twice. The values obtained for paclitaxel were $23 \pm 2(\mathrm{SD}) \mu \mathrm{M}$ in $0.4 \mathrm{M}$ glutamate and $4.5 \pm 0.1 \mu \mathrm{M}$ in $0.8 \mathrm{M}$ glutamate. ${ }^{c}$ Twice cycled microtubule protein was prepared following the procedure of Williams and Lee ${ }^{27}$ and stored in liquid nitrogen before use. Quantification of tubulin polymerization potency was accomplished following a modified procedure of Swindell et al.28 These modifications, in part, result in the expression of tubulin polymerization potency as an effective concentration for any given compound. For this method, different compound concentrations in polymerization buffer (0.1 M MES, $1 \mathrm{mM} \mathrm{EGTA}, 0.5 \mathrm{mM} \mathrm{MgCl}$, $\mathrm{pH}$ 6.6) were added to microtubule protein in polymerization buffer at $37{ }^{\circ} \mathrm{C}$ in microcuvette wells of a Beckman (Beckman Instruments) model DU 7400 UV spectrophotometer. A final microtubule protein concentration of $1.0 \mathrm{mg} / \mathrm{mL}$ and compound concentrations of $2.5,5.0$, and $10 \mu \mathrm{M}$ were used. I nitial slopes of absorbance change measured every $10 \mathrm{~s}$ were calculated by the program accompanying the instrument after initial and final times of the linear region encompassing at least three time points were manually defined. Under these conditions linear variances were generally $<10^{-6}$, slopes ranged from 0.03 to $0.002 \mathrm{~A}$ unit/min, and maximum absorbance was $0.15 \mathrm{~A}$ unit. Effective concentration $\left(\mathrm{EC}_{0.01}\right)$ is defined as the interpolated concentration capable of inducing an initial slope of $0.01 \mathrm{~A}$ unit/min and is calculated using the formula: $\mathrm{EC}_{0.01}=$ concentration/slope. ${ }^{\mathrm{d}} \mathrm{Human} \mathrm{Burkitt}$ Iymphoma CA46 cells were grown in 5.0-mL suspension cultures and counted after $24 \mathrm{~h}$ of growth at $37{ }^{\circ} \mathrm{C}$ under $5 \% \mathrm{CO}_{2}{ }^{25} \mathrm{IC} \mathrm{C}_{50}$ values, defined as the drug concentration required to reduce the increase in cell number by $50 \%$, were determined in a minimum of two independent experiments. The average $I C_{50}$ value for paclitaxel was $30 \mathrm{nM}$. The highest drug concentration evaluated was $100 \mathrm{nM}$. e The human ovarian carcinoma line $1 \mathrm{~A} 9$ was derived by subcloning line A2780, ${ }^{20}$ and cells were grown in 96 -well titer plates for $96 \mathrm{~h}$ at $37{ }^{\circ} \mathrm{C}$ under $5 \% \mathrm{CO}_{2}$ in $0.1 \mathrm{~mL}$ of medium. The $\mathrm{IC}_{50}$ value was the drug concentration required to inhibit by $50 \%$ the increase in cell protein. ${ }^{26} \mathrm{The}$ average IC 50 value for paclitaxel was $2.1 \mathrm{nM}$. The highest drug concentration examined was $100 \mathrm{nM}$. ${ }^{\mathrm{f}}$ The paclitaxel-resistant line 1A9(PTX22) was derived from 1A9 by a one-step selection in the presence of paclitaxel and verapamil (added to minimize likelihood of selecting a P-glycoprotein-expressing line). 1A9(PTX22) expresses an altered $\beta$-tubulin that confers resistance to paclitaxel. ${ }^{21}$ I $C_{50}$ values for each drug were obtained in tandem with I $C_{50}$ values for the parental line $1 A 9$. The average I $C_{50}$ value for paclitaxel was $44 \mathrm{nM}$, so that the relative resistance of 1A9(PTX22) to the parental line for paclitaxel was 21-fold. The values presented in the table are the relative resistance for the anal ogue divided by the relative resistance for paclitaxel. NM means no I $C_{50}$ value was obtained for the analogue in the parental and/or resistant line. ${ }^{9}$ Cells of the human col on carcinoma line HCT116 were grown in 96 -well titer plates for $48 \mathrm{~h}$ at 37 ${ }^{\circ} \mathrm{C}$ under $5 \% \mathrm{CO}_{2}$ in $0.1 \mathrm{~mL}$ of medium. The I $\mathrm{C}_{50}$ value was the drug concentration required to inhibit by $50 \%$ the increase in cell protein. The average I $\mathrm{C}_{50}$ values for paclitaxel in the experiments presented here were in the range $2.0-2.5 \mathrm{nM}$. $\mathrm{h} \mathrm{NM}$, not meaningful, indicating that no IC 50 value was obtained (i.e., IC $50>100 \mathrm{nM}$ ) for the parent line, for the resistant line, or for both lines.

tubule protein assay. Compounds that showed the greatest differential activities between the three lines were the following: $\mathbf{1 4} \mathbf{b f}, \mathbf{b l , b p , d k}$ (ovarian line rela- tively sensitive); 14aa, bc, be, bg,bo,ca,cf,dg,dh,ea,eb, ec,ed (Burkitt line relatively sensitive); 14ad,bk,da (colon line relatively sensitive); 14da,dn (ovarian line 


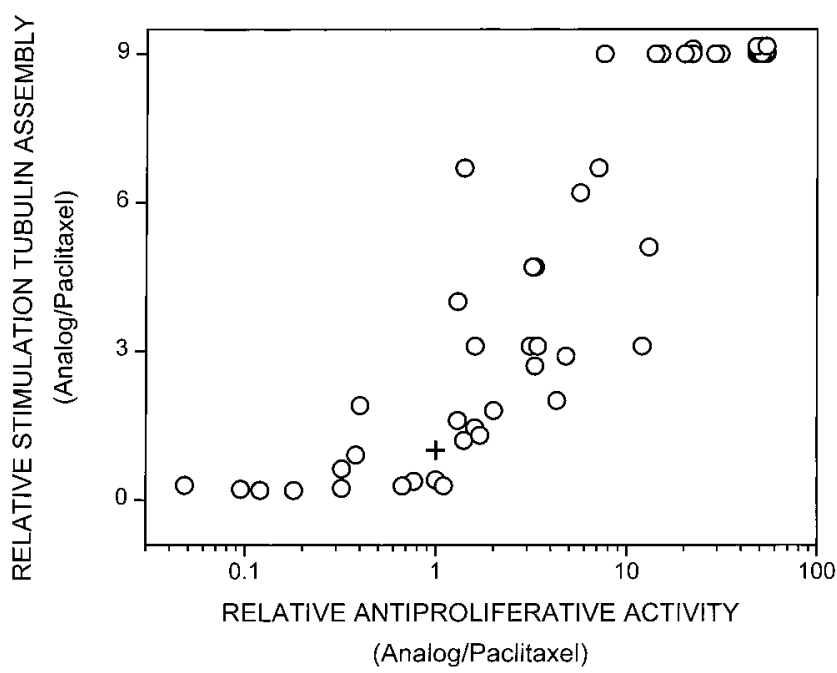

Figure 1. Correlation of analogue effects on stimulation of tubulin assembly and on inhibition of growth of human ovarian carcinoma 1A9 cells. The data of Table 2, columns 3 and 4 (the values for compounds $\mathbf{1 4 a b}, \mathbf{b a}, \mathbf{b j}$ were averaged) are plotted against the data of column 7 . The cross indicates the position of paclitaxel. Activities relative to paclitaxel are plotted in both dimensions. The cluster of symbols at the upper right represents 11 analogues inactive in both assays at the highest drug concentrations examined. The correlation coefficient for these data is 0.903 (obtained with Origin Microcal Version 4.1).

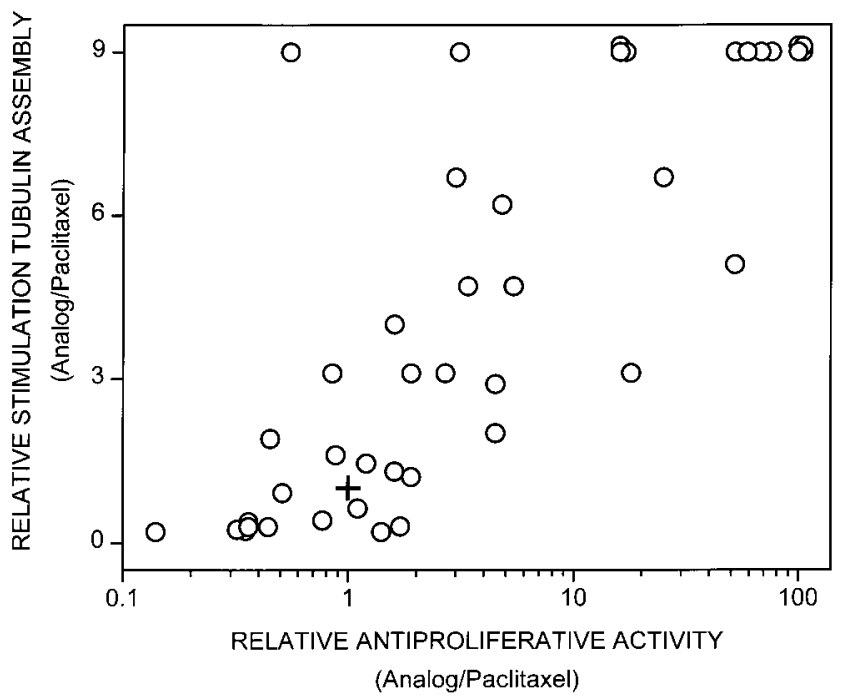

Figure 2. Correlation of analogue effects on stimulation of tubulin assembly and on inhibition of growth of human colon carcinoma HCT116 cells. The data of Table 2, columns 3 and 4 (the values for compounds $\mathbf{1 4 a b}, \mathbf{b a}, \mathbf{b j}$ were averaged) are plotted against the data of column 9 . The cross indicates the position of paclitaxel. Activities relative to paclitaxel are plotted in both dimensions. The cluster of symbols at the upper right represents 4 analogues inactive in the tubulin assay at the highest drug concentration examined and with $I_{50}$ values greater than $200 \mathrm{nM}$ in the cell proliferation assay. The correlation coefficient for these data is 0.815 (obtained with Origin Microcal Version 4.1).

relatively resistant); and $\mathbf{1 4 e c}$ (colon line relatively resistant).

We al so evaluated the tubulin assay for its ability to predict a compound's antiprol iferative activity. Figures 1 and 2 present graphical representations of the data of Table 2, with the purified tubulin polymerization data (both the 0.4 and $0.8 \mathrm{M}$ glutamate results) plotted against the cell growth data obtained with the parental ovarian line (Figure 1 ) and the col on line (Figure 2). The best correlation of the tubulin assembly activity was with the ovarian line. Every compound, except two, that was more active than paclitaxel with tubulin was also more active as an inhibitor of ovarian cell growth, and the exceptions were similar to paclitaxel in their cytotoxicity toward the ovarian cells. Conversely, among compounds with greater antiproliferative activity than paclitaxel, only one was less potent than paclitaxel in enhancing tubulin assembly. The poorest correlation of the tubulin assembly data was with inhibition of growth of the Burkitt cells (data not shown).

As was noted above, no anal ogue was able to reverse completely paclitaxel resistance based on an altered $\beta$-tubulin in the ovarian line 1A9(PTX22). ${ }^{21}$ Nevertheless, there did appear to be significant partial reversal with a number of analogues. Restoration of taxoid sensitivity appeared to be greatest (analogue/paclitaxel $<0.4$ ) with compounds $\mathbf{1 4} \mathbf{b a}, \mathbf{b c}, \mathbf{b i}, \mathbf{b k}, \mathbf{d j}$. Of these, only 14bi,dj were more active than paclitaxel with purified tubulin, but, perhaps significantly, 14bk was among the compounds that were more active than paclitaxel in the microtubule protein screening assay.

Structure-Activity Relationships. This discussion will focus on the effects of this series of analogues in enhancing the assembly of purified tubulin. As noted above, correlations between the tubulin data and the cell growth data are strong, but not absolute. Note that, for ease of comparison, the compounds have been tabulated throughout, as far as possible, in order of increasing Hammett $\sigma$ constant, 22 and in no assay was there a trend of activity with changes in the electronwithdrawing or electron-donating effect of a substituent.

As reported initially, ${ }^{8}$ and confirmed more extensively here, with benzenoid analogues substituent position was highly important. Among compounds with single parasubstituents (compounds $\mathbf{1 4} \mathbf{c a}-\mathbf{c h}$ ), only $\mathbf{1 4 c d}$ with a p-fluoro group yielded an $\mathrm{IC}_{50}$ value, and it was 6.2fold higher than the value obtained with paclitaxel. Moreover, introduction of a para-substituent into an otherwise hyperactive analogue reduces the apparent interaction with tubulin (cf. 14dh with 14bj, 14dj with $\mathbf{1 4 b l}$, 14dc with $\mathbf{1 4 d b}$, 14dl with $\mathbf{1 4 d k}$, and $\mathbf{1 4 d f}$ with $\mathbf{1 4 d g}$ ), although in one case (14dj) the resulting compound is still more active than paclitaxel. Since the negligible activity of the para-substituted derivatives $(\mathbf{1 4} \mathbf{c a}-\mathbf{c h})$ is independent of the electronic nature of the substituent, it seems likely that there is a significant steric effect reducing binding of para-substituted C-2 benzenoid analogues to the paclitaxel site on tubulin.

In view of the apparent steric origin for the lack of activity of the para-substituted anal ogues, we reasoned that the problem might be avoided with meta-substitution. Such analogues theoretically could rotate about the bond between the aryl ring and the carbonyl group. Consistent with this idea, four analogues with relatively small meta-substituents (14bf, methoxy; 14bi, azido; 14bl, chloro; 14bp, cyano) were significantly more active than paclitaxel as inducers of tubulin assembly. Other factors, perhaps electronic in origin, are clearly involved in the interaction of C-2-modified taxoids with tubulin, however, since some analogues with relatively small substituents had moderately (14ba, ethoxy; 14bg, thi- 
omethyl; 14bj, fluoro; 14bq, nitro) or severely (14be, hydroxy; 14bm, acetyl) reduced activity, and one compound with a relatively bulky bromo group (14bn) was more active than paclitaxel. Thus, significant steric trends are evident in the alkoxy series (methoxy $>$ ethoxy $>$ propoxy) but not in the halide series $(\mathrm{Br}>\mathrm{Cl}$ $>\mathrm{F}>\mathrm{I}$ ). With the exception of the m-bromide 14bn, no substituent group with a molecular mass greater than 42 gave an analogue with activity greater than that of paclitaxel.

Only a small number of ortho-substituted benzoyl analogues were prepared (compounds 14aa-ad), and all had small substituents. These were less active than the analogous meta-substituted compounds, but the o-azi do derivative (14ad) was significantly more active than paclitaxel; it was also more cytotoxic than paclitaxel toward the ovarian and colon carcinoma cell lines.

A number of analogues with multiple substituents on the benzoyl ring were also prepared $(\mathbf{1 4 d a}-\mathbf{d n})$. As noted above, a para-substituent al ways made a negative impact on activity, and generally a major negative impact. Other substitution patterns were more variable. In four of five analogues, a di-meta-substituent pattern led to loss of activity (14dg, methoxy; 14di, azido; 14dm, chloro; 14dn, nitro; $\mathbf{1 4 d m}$, however, did have nomi nally ${ }^{23}$ greater activity than paditaxel). The exception was the di-m-fluoro analogue 14dk, which was more active than the mono-m-fluoro compound 14bj. With ortho-meta-disubstitution, the results obtained depended on whether the substituents were on the same or opposite sides of the benzene ring, although only two examples were available. Thus, if the substituents were vicinal, the ortho effect dominated, with the di substituted analogues less active than the monosubstituted meta-compounds (cf. 14da with 14bj; 14dd with 14bf). In contrast, when the substituents were on opposite sides of the benzene ring, there was no loss or even enhancement of the activity observed with the monosubstituted meta-compounds (cf. 14db with 14bj; 14de with 14bf).

Finally, in our effort to obtain anal ogues more active than paclitaxel, we prepared a number of analogues with non-benzenoid substituents at position C-2. The nonaromatic analogues, such as acetyl (14ef) and valeryl (14eg), were significantly less active than paclitaxel, and even the aromatic analogues such as the furoyl analogues $\mathbf{1 4 e c}$,ed were also significantly less active than paclitaxel in all assays. Only the thiophenecarbonyl analogues 14ea,eb showed improved activity and then only in the antiproliferative studies with Burkitt cells. These results parallel those obtained by Nicolaou et al., ${ }^{9 d}$ who observed that the thiophenecarbonyl analogues were the only non-benzenoid 2-acyl analogues that showed improved antiproliferative activity as compared with paclitaxel, and this enhanced activity was only observed in a few cell lines.

\section{Conclusions}

We have evaluated a number of biological activities of 50 analogues of paclitaxel modified at position C-2. Enhanced activity was observed only in compounds that retain a benzoyl group, provided they have a relatively small meta-substituent or an o-azido group. No significant improvement in activity was observed over the previously described compound 14bi (2-debenzoyl-2-mazidobenzoyl paclitaxel). The best correlation between tubulin assembly effects measured in a biochemical assay and antiproliferative effects on cells was observed in an ovarian carcinoma line designated 1A9. None of the analogues synthesized could completely overcome paclitaxel resistance due to an altered $\beta$-tubulin, but compound 14bi and a number of other analogues partially overcame this type of resistance to paclitaxel.

\section{Experimental Section}

General Experimental Procedures. All chemicals other than solvents were obtained from Aldrich Chemical Co. and used without further purification. All anhydrous reactions were performed under Ar. THF was dried over sodium/ benzophenone. All reactions were monitored by TLC (silica gel, GF) and the plates examined with UV light and devel oped with vanillin spray. ${ }^{1} \mathrm{H}$ and ${ }^{13} \mathrm{C}$ NMR spectra were obtained in $\mathrm{CDCl}_{3}$ at 270 and $400 \mathrm{M} \mathrm{Hz}$ for proton spectra and assigned primarily by comparison of chemical shifts and coupling constants with those of related compounds and by appropriate 2D NMR techniques. Coupling constants are reported in $\mathrm{Hz}$. ${ }^{13} \mathrm{C} N M R$ spectra were assigned using HETCOR and DEPT spectra. ${ }^{1} \mathrm{H}$ NMR spectra sometimes showed the presence of traces of ethyl acetate, since paclitaxel and its derivatives retain ethyl acetate very tightly, and it cannot be removed completely even on prolonged treatment in vacuo at $38^{\circ} \mathrm{C}$. Exact mass measurements were performed at the Nebraska Center for Mass Spectrometry. All compounds were homogeneous by TLC and were $>90 \%$ pure as judged by NMR. All compounds showing activity greater than paclitaxel were also analyzed by HPLC (C-18 column, $\mathrm{H}_{2} \mathrm{O} / \mathrm{MeOH}, 30: 70$ ) and repurified if necessary to $95 \%$ purity or better.

2-0,7-0,3'-N-Tri(tert-butoxycarbonyl)paclitaxel (4). A solution of 2'-O,7-O,3'-N-tri(tert-butoxycarbonyl)-1,2-( $\alpha$-tertbutoxybenzylideneacetal)paclitaxel (5) (35 mg, $0.027 \mathrm{mmol}$ ) in $\mathrm{CHCl}_{3}(2 \mathrm{~mL}$ ) was stirred at room temperature for $24 \mathrm{~h}$. It showed disappearance of starting compound with the formation of new polar compound on TLC. The reaction mixture was concentrated and dried under reduced pressure to afford 2'-O,7-O, 3'-N-tri(tert-butoxycarbonyl)paclitaxel (4) (30 mg, 94\%). ${ }^{1} \mathrm{H}$ NMR: $\delta 1.05$ (s 9H), 1.10 (s 6H), 1.36 (s 9H), 1.38$1.41(\mathrm{~m}, 2 \mathrm{H}), 1.44(\mathrm{~s} 9 \mathrm{H}), 1.52$ (s $1 \mathrm{H}), 1.74(\mathrm{~s} \mathrm{3H}), 1.84(\mathrm{~s} \mathrm{3H})$, $1.87-1.91(\mathrm{~m}, 1 \mathrm{H}), 2.09(\mathrm{~s} 3 \mathrm{H}), 2.39(\mathrm{~s} 3 \mathrm{H}), 2.58-2.64(\mathrm{~m}, 1 \mathrm{H})$, $3.87(\mathrm{~d}, \mathrm{~J}=7.02 \mathrm{~Hz}, 1 \mathrm{H}), 4.11(\mathrm{~d}, \mathrm{~J}=7.17 \mathrm{~Hz}, 1 \mathrm{H}), 4.13(\mathrm{~d}$, $\mathrm{J}=7.17 \mathrm{~Hz}, 1 \mathrm{H}), 4.27(\mathrm{~d}, \mathrm{~J}=8.24 \mathrm{~Hz}, 1 \mathrm{H}), 4.94(\mathrm{~d}, \mathrm{~J}=7.78$ $\mathrm{Hz}, 1 \mathrm{H}), 5.31-5.36(\mathrm{~m}, 1 \mathrm{H}), 5.60(\mathrm{~d}, \mathrm{~J}=7.17 \mathrm{~Hz}, 1 \mathrm{H}), 5.84(\mathrm{~d}$, $\mathrm{J}=11.14 \mathrm{~Hz}, 1 \mathrm{H}), 5.92(\mathrm{~d}, \mathrm{~J}=11.29 \mathrm{~Hz}, 1 \mathrm{H}), 5.97(\mathrm{t}, \mathrm{J}=$ $9.00 \mathrm{~Hz}, 1 \mathrm{H}), 6.46(\mathrm{~s} 1 \mathrm{H}), 7.12-7.15(\mathrm{dd}, \mathrm{J}=7.78$ and 7.47 $\mathrm{Hz}, \mathrm{H}), 7.33-7.41(\mathrm{~m}, 4 \mathrm{H}), 7.47-7.56(\mathrm{~m}, 4 \mathrm{H}), 7.62-7.69(\mathrm{~m}$, $4 \mathrm{H}), 8.07(\mathrm{~d}, \mathrm{~J}=7.01 \mathrm{~Hz}, 2 \mathrm{H}) .{ }^{13} \mathrm{C} N M R: \delta 10.94,14.18,20.69$, $21.29,22.34,26.22,27.22,27.51,27.65,33.25,34.61,42.96$, $46.44,56.19,60.84,71.05,74.13,74.29,74.73,75.02,78.80$, $80.30,82.77,83.37,83.55,83.99,127.90,128.11,128.50$, $128.56,128.99,129.28,129.64,130.12,131.51,132.45,133.77$, $134.84,137.78,141.50,151.74,152.11,152.82,166.88,168.30$, 169.24, 170.12, 173.22, 202.08. HRFABMS: $\mathrm{m} / \mathrm{z}[\mathrm{M}+\mathrm{Na}]^{+}$ $1176.4796\left(\mathrm{C}_{62} \mathrm{H}_{75} \mathrm{NO}_{20} \mathrm{Na}\right.$ requires 1176.4780$)$.

2'-0,7-0,3'-N-Tri(tert-butoxycarbonyl)-1,2-( $\alpha$-tert-butoxybenzylideneacetal)paclitaxel (5). To a stirred solution of paclitaxel (1) $(30 \mathrm{mg}, 0.035 \mathrm{mmol})$ in dry acetonitrile (1.5 $\mathrm{mL}$ ) was added di-tert-butyl dicarbonate $(76.3 \mathrm{mg}, 0.35 \mathrm{mmol})$ under Ar. After the mixture stirred for $5 \mathrm{~min}$, DMAP $(17 \mathrm{mg})$ was added at room temperature. The reaction mixture was stirred for $4 \mathrm{~h}$ at room temperature and then diluted with 10 $\mathrm{mL}$ of EtOAc. The organic layer was washed with water and brine, dried over $\mathrm{Na}_{2} \mathrm{SO}_{4}$, and evaporated to furnish a paleyellow residue, which was purified on PTLC (Analtech, 1000 $\mu \mathrm{m}$; hexane/EtOAc, 3:1) to give 2'-O,7-O,3'-N-tri (tert-butoxycarbonyl)-1,2-( $\alpha$-tert-butoxybenzylideneacetal)paclitaxel (5) (38 mg, 86\%). ${ }^{1} \mathrm{H}$ NMR: $\delta 0.95(\mathrm{~s} 9 \mathrm{H}), 1.00(\mathrm{~s} 9 \mathrm{H}), 1.16(\mathrm{~s} \mathrm{3H})$, $1.17(\mathrm{~s} 3 \mathrm{H}), 1.28(\mathrm{~s} 9 \mathrm{H}), 1.45(\mathrm{~s} 9 \mathrm{H}), 1.51-1.64(\mathrm{~m}, 2 \mathrm{H}), 1.66$ (s 1H), $1.74(\mathrm{~s} 3 \mathrm{H}), 1.82(\mathrm{~s} 3 \mathrm{H}), 1.96-2.03(\mathrm{~m}, 1 \mathrm{H}), 2.07$ (s 3H), 
$2.23(\mathrm{~s} \mathrm{3H}), 2.68-2.76(\mathrm{~m}, 1 \mathrm{H}), 3.42(\mathrm{~d}, \mathrm{~J}=5.04 \mathrm{~Hz}, 1 \mathrm{H}), 4.26$ $(\mathrm{d}, \mathrm{J}=5.03 \mathrm{~Hz}, 1 \mathrm{H}), 4.73(\mathrm{~d}, \mathrm{~J}=8.55 \mathrm{~Hz}, 1 \mathrm{H}), 4.76(\mathrm{~d}, \mathrm{~J}=$ $8.55 \mathrm{~Hz}, 1 \mathrm{H}), 5.07(\mathrm{~d}, \mathrm{~J}=8.85 \mathrm{~Hz}, 1 \mathrm{H}), 5.32-5.36(\mathrm{dd}, \mathrm{J}=$ 7.63 and $7.33 \mathrm{~Hz}, 1 \mathrm{H}), 5.73(\mathrm{t}, \mathrm{J}=8.54 \mathrm{~Hz}, 1 \mathrm{H}), 5.81(\mathrm{~d}, \mathrm{~J}=$ $11.14 \mathrm{~Hz}, 1 \mathrm{H}), 5.91(\mathrm{~d}, \mathrm{~J}=10.99 \mathrm{~Hz}, 1 \mathrm{H}), 6.45(\mathrm{~s} 1 \mathrm{H}), 6.74-$ $6.77(\mathrm{dd}, \mathrm{J}=7.48$ and $6.87 \mathrm{~Hz}, 1 \mathrm{H}), 6.99-7.03(\mathrm{dd}, \mathrm{J}=7.63$ and $7.78 \mathrm{~Hz}, 2 \mathrm{H}), 7.34-7.38(\mathrm{~m}, 5 \mathrm{H}), 7.44-7.49(\mathrm{~m}, 3 \mathrm{H}), 7.57$ $(d, J=7.02 \mathrm{~Hz}, 4 \mathrm{H}) .{ }^{13} \mathrm{C} N M R: \delta$ 11.14, 14.41, 20.68, 20.80, $22.15,25.74,27.18,27.44,27.64,30.30,33.95,34.04,41.55$, $43.62,57.85,71.42,74.05,74.49,74.50,76.38,79.66,82.77$, $83.24,83.43,84.31,86.36,118.49,126.40,127.75,127.80$, $128.08,128.30,128.33,128.84,129.28,131.43,131.60,134.09$, $137.79,141.72,142.85,151.67,152.20,152.89,168.41,169.13$, 170.00, 173.07, 203.39. HRFABMS: $\mathrm{m} / \mathrm{z}[\mathrm{M}+\mathrm{H}]^{+} 1210.5586$ $\left(\mathrm{C}_{66} \mathrm{H}_{84} \mathrm{NO}_{20}\right.$ requires 1210.5580$)$.

2-O-(tert-Butoxycarbonyl)paclitaxel (6). Paditaxel (1) (85.3 $\mathrm{mg}, 0.1 \mathrm{mmol}$ ) and acetonitrile ( $2 \mathrm{~mL}$, freshly dried and distilled over $\mathrm{CaH}_{2}$ ) were added to a flame-dried $25-\mathrm{mL}$ roundbottom flask under Ar. To this solution was added $21.8 \mathrm{mg}$ $(0.1 \mathrm{mmol})$ of di-tert-butyl dicarbonate in $2.0 \mathrm{~mL}$ of dry $\mathrm{CH}_{3^{-}}$ $\mathrm{CN}$ under Ar. After the mixture stirred for $5 \mathrm{~min}$, DMAP (5 $\mathrm{mg}$ ) was added at $0{ }^{\circ} \mathrm{C}$. The reaction mixture was stirred for $2 \mathrm{~h}$ at room temperature and worked up by diluting with EtOAc. Solvents were removed on a rotary evaporator. The pale-yellow residue was dissolved in EtOAc and washed sequentially with dilute $\mathrm{HCl}$ and cold $0.05 \mathrm{~N} \mathrm{NaHCO}_{3}$. The organic solution was washed with brine, dried over $\mathrm{Na}_{2} \mathrm{SO}_{4}$, and evaporated to give 2'-O-(tert-butoxycarbonyl)paclitaxel (6) (95 mg, 99.6\%), $\mathrm{R}_{\mathrm{f}}$ (hexane/EtOAc, 1:1) 0.36. ${ }^{1} \mathrm{H}$ NMR: $\delta 1.12$ (s 3H), 1.23 (s 3H), 1.45 (s 9H), $1.67(\mathrm{~s} \mathrm{3H}), 1.85(\mathrm{~s} 1 \mathrm{H}), 1.90$ (s 3H), 2.16-2.22 (m, 1H), $2.21(\mathrm{~s} 3 \mathrm{H}), 2.35-2.41(\mathrm{~m}, 2 \mathrm{H}), 2.44$ (s $3 \mathrm{H}), 2.51-2.55(\mathrm{~m}, 2 \mathrm{H}), 3.80(\mathrm{~d}, \mathrm{~J}=7.02 \mathrm{~Hz}, 1 \mathrm{H}), 4.18(\mathrm{~d}$, $\mathrm{J}=8.21 \mathrm{~Hz}, 1 \mathrm{H}), 4.30(\mathrm{~d}, \mathrm{~J}=8.54 \mathrm{~Hz}, 1 \mathrm{H}), 4.42(\mathrm{~m}, 1 \mathrm{H}), 4.46$ $(\mathrm{d}, \mathrm{J}=9.46 \mathrm{~Hz}, 1 \mathrm{H}), 5.39(\mathrm{~d}, \mathrm{~J}=2.9 \mathrm{~Hz}, 1 \mathrm{H}), 5.68(\mathrm{~d}, \mathrm{~J}=$ $7.17 \mathrm{~Hz}, 1 \mathrm{H}), 5.92-5.95(\mathrm{dd}, \mathrm{J}=2.44$ and $9.3 \mathrm{~Hz}, 1 \mathrm{H}), 6.25(\mathrm{t}$, $\mathrm{J}=8.85 \mathrm{~Hz}, 1 \mathrm{H}), 6.28(\mathrm{~s} \mathrm{H}), 6.98(\mathrm{~d}, \mathrm{~J}=9.31 \mathrm{~Hz}, 1 \mathrm{H}), 7.40-$ $7.43(\mathrm{~m}, 7 \mathrm{H}), 7.47-7.50(\mathrm{~m}, 3 \mathrm{H}), 7.52-7.61(\mathrm{~m}, 1 \mathrm{H}), 7.73(\mathrm{~d}$, $\mathrm{J}=7.02 \mathrm{~Hz}, 2 \mathrm{H}), 8.11(\mathrm{~d}, \mathrm{~J}=7.02 \mathrm{~Hz}, 2 \mathrm{H}) .{ }^{13} \mathrm{C} N M R: \delta 9.58$, $14.81,20.81,22.15,22.66,26.78,27.58,35.49,35.57,43.17$, $45.53,52.84,58.47,71.93,72.09,75.08,75.59,75.86,76.41$, $79.06,81.01,84.14,84.42,126.65,127.16,128.37,128.63$, $128.69,129.00,129.16,130.19,131.95,132.68,133.59,133.64$, $136.97,142.83,152.33,166.96,167.14,168.33,169.84,171.25$, 203.81. HRFABMS: $\mathrm{m} / \mathrm{z}[\mathrm{M}+\mathrm{H}]^{+} 954.3908\left(\mathrm{C}_{52} \mathrm{H}_{60} \mathrm{NO}_{16}\right.$ requires 954.3912).

2-0-(tert-Butoxycarbonyl)-7-0-(triethylsilyl)paclitaxel (7). I midazole ( $34 \mathrm{mg}, 5 \mathrm{mmol}$ ) followed by triethylsilyl chloride $(83.9 \mu \mathrm{L}, 0.5 \mathrm{mmol})$ were slowly added to a stirred solution of 2'-O-(tert-butoxycarbonyl)paclitaxel (6) $(95.3 \mathrm{mg}$, $0.1 \mathrm{mmol}$ ) in $2 \mathrm{~mL}$ of dry DMF at $0{ }^{\circ} \mathrm{C}$ under Ar. The reaction mixture was stirred for $3 \mathrm{~h}$ and quenched with EtOAc. The organic layer was washed several times with $\mathrm{H}_{2} \mathrm{O}$ and brine and dried with $\mathrm{Na}_{2} \mathrm{SO}_{4}$. The solvent was evaporated to obtain pure 2'-O-(tert-butoxycarbonyl)-7-O-(triethylsilyl)paclitaxel (7) (94.9 mg, 89\%), $\mathrm{R}_{\mathrm{f}}$ (hexane/EtOAc, 1:1) 0.66. ${ }^{1 \mathrm{H}} \mathrm{NMR}: \delta$, $0.52-0.60(\mathrm{~m}, 6 \mathrm{H}), 0.92(\mathrm{t}, \mathrm{J}=15.9 \mathrm{~Hz}, 9 \mathrm{H}), 1.17(\mathrm{~s} 3 \mathrm{H}), 1.21$ (s 3H), $1.46(\mathrm{~s} 9 \mathrm{H}), 1.68(\mathrm{~s} 3 \mathrm{H}), 1.76(\mathrm{~s} 1 \mathrm{H}), 1.85-1.91(\mathrm{~m}, 1 \mathrm{H})$, $2.03(\mathrm{~s} \mathrm{3H}), 2.12-2.19(\mathrm{~m}, 1 \mathrm{H}), 2.16(\mathrm{~s} 3 \mathrm{H}), 2.35-2.53(\mathrm{~m}, 2 \mathrm{H})$, $2.44(\mathrm{~s} 3 \mathrm{H}), 3.81(\mathrm{~d}, \mathrm{~J}=7.17 \mathrm{~Hz}, 1 \mathrm{H}), 4.18(\mathrm{~d}, \mathrm{~J}=8.4 \mathrm{~Hz}$, $1 \mathrm{H}), 4.31(\mathrm{~d}, \mathrm{~J}=8.2 \mathrm{~Hz}, 1 \mathrm{H}), 4.44-4.49(\mathrm{dd}, \mathrm{J}=6.7$ and 6.4 $\mathrm{Hz}, 1 \mathrm{H}), 4.93(\mathrm{~d}, \mathrm{~J}=9.5 \mathrm{~Hz}, 1 \mathrm{H}), 5.42(\mathrm{~d}, \mathrm{~J}=9.5 \mathrm{~Hz}, 1 \mathrm{H})$, $5.69(\mathrm{~d}, \mathrm{~J}=6.7 \mathrm{~Hz}, 1 \mathrm{H}), 5.94-5.97(\mathrm{dd}, \mathrm{J}=2.7$ and $9.5 \mathrm{~Hz}$, $1 \mathrm{H}), 6.24(\mathrm{t}, \mathrm{J}=9.15 \mathrm{~Hz}, 1 \mathrm{H}), 6.45(\mathrm{~s} 1 \mathrm{H}), 6.95(\mathrm{~d}, \mathrm{~J}=9.16$ $\mathrm{Hz}, 1 \mathrm{H}), 7.32-7.47(\mathrm{~m}, 7 \mathrm{H}), 7.48-7.51(\mathrm{~m}, 3 \mathrm{H}), 7.57-7.61(\mathrm{~m}$, $1 \mathrm{H}), 7.74(\mathrm{~d}, \mathrm{~J}=7.17 \mathrm{~Hz}, 2 \mathrm{H}), 8.12(\mathrm{~d}, \mathrm{~J}=7.17 \mathrm{~Hz}, 2 \mathrm{H}) .{ }^{13} \mathrm{C}$ NMR: $\delta 5.26,6.73,10.09,14.17,20.84,21.34,22.70,26.56$, $27.60,35.34,37.19,43.27,46.68,52.78,58.39,71.90,72.15$, $74.94,75.00,75.77,76.51,78.80,81.04,84.08,84.22,126.61$, $127.16,128.27,128.62,128.65,128.95,129.23,130.18,131.90$, 133.46, 133.58, 137.01, 140.47, 152.29, 167.03, 168.27, 169.16, 169.79, 201.82. HRFABMS: $\mathrm{m} / \mathrm{z}[\mathrm{M}+\mathrm{H}]^{+} 1068.4747\left(\mathrm{C}_{58} \mathrm{H}_{74^{-}}\right.$ $\mathrm{NO}_{16} \mathrm{Si}$ requires 1068.4776).

2',N-Di-O-(tert-butoxycarbonyl)-7-0-(triethylsilyl)paclitaxel (8). Di-tert-butyl dicarbonate (377.6 mg, $20 \mathrm{mmol}$ ) in $0.5 \mathrm{~mL}$ of $\mathrm{CH}_{3} \mathrm{CN}$ was added to a solution of 2'-O-(tertbutoxycarbonyl)-7-O-(triethylsilyl)paclitaxel (7) $(92.5 \mathrm{mg}, 0.09$ $\mathrm{mmol}$ ) in $0.5 \mathrm{~mL}$ of dry acetonitrile under Ar. After the mixture stirred for $5 \mathrm{~min}$ at room temperature, DMAP (8 mg) was added. The reaction mixture was stirred for $3 \mathrm{~h}$ at room temperature and diluted with EtOAc. Solvents were removed on a rotary evaporator. The residue was dissolved in EtOAc and the solution washed sequentially with cold dilute $\mathrm{HCl}$, cold $0.05 \mathrm{~N} \mathrm{NaHCO}_{3}, \mathrm{H}_{2} \mathrm{O}$, and brine and dried over $\mathrm{Na}_{2} \mathrm{SO}_{4}$. The solvent was evaporated to yield crude product, which was passed through a small silica gel column to yield pure $2^{\prime}, \mathrm{N}$ di-O-(tert-butoxycarbonyl)-7-O-(triethylsilyl)paclitaxel (8) (89 $\mathrm{mg}, 88 \%$ ), $\mathrm{R}_{\mathrm{f}}$ (hexane/EtOAc, 1:1) 0.55. ${ }^{1} \mathrm{H}$ NMR: $\delta 0.50-0.58$ $(\mathrm{m}, 6 \mathrm{H}), 0.90(\mathrm{t}, \mathrm{J}=7.78 \mathrm{~Hz}, 9 \mathrm{H}), 1.04(\mathrm{~s} 9 \mathrm{H}), 1.09$ (s 3H), $1.14(\mathrm{~s} 3 \mathrm{H}), 1.35$ (s 9H), $1.47-1.51(\mathrm{~m}, 1 \mathrm{H}), 1.63$ (s $3 \mathrm{H}), 1.73$ (s $1 \mathrm{H}), 1.79(\mathrm{~s} \mathrm{3H}), 1.83-1.93(\mathrm{~m}, 3 \mathrm{H}), 2.12$ (s 3H), 2.38 (s 3H), 2.46-2.54 (m, 1H), $3.73(\mathrm{~d}, \mathrm{~J}=7.17 \mathrm{~Hz}, 1 \mathrm{H}), 4.09(\mathrm{~d}, \mathrm{~J}=8.39$ $\mathrm{Hz}, 1 \mathrm{H}), 4.25(\mathrm{~d}, \mathrm{~J}=8.40 \mathrm{~Hz}, 1 \mathrm{H}), 4.42-4.46(\mathrm{~m}, 1 \mathrm{H}), 4.92(\mathrm{~d}$, $\mathrm{J}=8.24 \mathrm{~Hz}, 1 \mathrm{H}), 5.59(\mathrm{~d}, \mathrm{~J}=7.17 \mathrm{~Hz}, 1 \mathrm{H}), 5.87(\mathrm{~d}, \mathrm{~J}=11.29$ $\mathrm{Hz}, 1 \mathrm{H}), 5.96-6.01(\mathrm{~m}, 2 \mathrm{H}), 7.16(\mathrm{t}, \mathrm{J}=7.47 \mathrm{~Hz}, 1 \mathrm{H}), 7.31-$ $7.40(\mathrm{~m}, 5 \mathrm{H}), 7.47-7.54(\mathrm{~m}, 3 \mathrm{H}), 7.61-7.67(\mathrm{~m}, 4 \mathrm{H}), 8.06(\mathrm{~d}$, $\mathrm{J}=7.18 \mathrm{~Hz}, 2 \mathrm{H}) .{ }^{13} \mathrm{C} N M R$ : $\delta 5.26,6.70,10.03,13.96,20.79$, $21.15,22.43,26.41,27.21,27.50,34.57,37.10,43.07,46.59$, $58.28,60.68,71.14,72.06,74.34,74.89,74.93,78.78,80.56$, $83.32,83.54,84.30,127.89,128.11,128.46,128.51,128.98$, $129.37,129.59,130.10,131.51,133.12,133.68,134.78,137.73$, $140.71,151.75,152.86,166.93,169.07,169.10,170.19,173.16$, 201.89. HRFABMS: $\mathrm{m} / \mathrm{z}[\mathrm{M}+\mathrm{H}]^{+} 1168.5282\left(\mathrm{C}_{63} \mathrm{H}_{82} \mathrm{NO}_{18}\right.$ requires 1168.5301).

2'N-Di-O-(tert-butoxycarbonyl)-2-debenzoyl-7-0-(triethylsilyl)paclitaxel (9). A $0.1 \mathrm{~N} \mathrm{LiOH}$ solution $(0.45 \mathrm{~mL})$ was added to a stirred solution of 2',7-di-O-(tert-butoxycarbonyl)-7-O-(triethylsilyl)paclitaxel $(8)(45 \mathrm{mg}, 0.038 \mathrm{mmol}$ ) in 4.5 $\mathrm{mL}$ of $\mathrm{THF}$ at $0{ }^{\circ} \mathrm{C}$. The ice bath was removed, and the solution was stirred for $2 \mathrm{~h}$ at room temperature. TLC showed the presence of two new spots at lower $R_{f}$ in addition to starting material. The reaction mixture was diluted with ether, and the solution was washed with brine. The brine layer was washed with additional ether, and the combined organic layer was dried over $\mathrm{Na}_{2} \mathrm{SO}_{4}$ and evaporated. The crude product was purified on PTLC (Analtech, $500 \mu \mathrm{m}$; hexane/EtOAC, 1:1). The slower moving band was scraped and extracted to give 2',N-di-O-(tert-butoxycarbonyl)-2-debenzoyl-7-O-(triethylsilyl)paclitaxel (9) (15.3 mg, 38\%; 76\% yield based on unrecovered starting material). The faster moving band corresponded to the rearranged paclitaxel 10. The product $\mathbf{9}$ had $\mathrm{R}_{\mathrm{f}}$ (hexane/ EtOAc, 2:1) 0.21. ${ }^{1} \mathrm{H}$ NMR: $\delta 0.59$ (q, 6H), 0.92 (t, 9H), 1.18 (s $3 \mathrm{H}), 1.25$ (s 3H), $1.30(\mathrm{~s} 9 \mathrm{H}), 1.48(\mathrm{~s} 9 \mathrm{H}), 1.65$ (s 3H), 2.15 (s $3 \mathrm{H}), 2.16(\mathrm{~s} 3 \mathrm{H}), 2.30(\mathrm{~s} 3 \mathrm{H}), 2.55(\mathrm{~m}, 2 \mathrm{H}), 3.37(\mathrm{~d}, \mathrm{~J}=6.8$ $\mathrm{Hz}, 1 \mathrm{H}), 3.86(\mathrm{bt}, \mathrm{J}=4.0 \mathrm{~Hz}, 1 \mathrm{H}), 4.4(\mathrm{dd}, \mathrm{J}=6.4,3.7 \mathrm{~Hz}$, $1 \mathrm{H}), 4.58(\mathrm{bs}, 2 \mathrm{H}), 4.95(\mathrm{~d}, \mathrm{~J}=10.4 \mathrm{~Hz}, 1 \mathrm{H}), 5.95(\mathrm{~d}, \mathrm{~J}=10.9$ $\mathrm{Hz}, 1 \mathrm{H}), 6.0(\mathrm{~m}, 1 \mathrm{H}), 6.08(\mathrm{~d}, \mathrm{~J}=10.9 \mathrm{~Hz}, 1 \mathrm{H}), 6.32(\mathrm{~s} 1 \mathrm{H})$, 7.25-7.8 (m, 15H). MS: $\mathrm{m} / \mathrm{z} 1064\left(\mathrm{M}+\mathrm{H}^{+}, 100 \%\right)$.

2 ,N-Di-O-(tert-butoxycarbonyl)-7-O-(triethylsilyl)paclitaxel (8) from $2, \mathrm{~N}-\mathrm{Di}$-O-(tert-butoxycarbonyl)-2-debenzoyl-7-O-(triethylsilyl)paclitaxel (9). A sample of $2^{\prime}, \mathrm{N}$ di-O-(tert-butoxycarbonyl)-2-debenzoyl-7-O-(triethylsilyl)paclitaxel (9) (2 mg, $0.0018 \mathrm{mmol})$ was treated with benzoic acid (4.59 mg, $0.0338 \mathrm{mmol}), \mathrm{DCC}(7.75 \mathrm{mg}, 0.038 \mathrm{mmol})$, and a catalytic amount of PP in dry toluene $(10 \mu \mathrm{L})$ under Ar. The mixture was stirred overnight at $50{ }^{\circ} \mathrm{C}$, and the solvent was removed on a rotary evaporator. The crude reaction mixture was purified by PTLC (500- $\mu \mathrm{m}$ layer; EtOAc/hexane, $1: 2)$ to yield 2',N-di-O-(tert-butoxycarbonyl)-7-O-(triethylsilyl)paclitaxel (8) (1.5 mg, 68\%), identical with material prepared directly from paclitaxel.

Conversion of $\mathbf{2}^{\prime}, \mathrm{N}-\mathrm{Di}$-O-(tert-butoxycarbonyl)-7-O(triethylsilyl)paclitaxel (8) to Paclitaxel (1). 2',N-Di-O(tert-butoxycarbonyl)-7-O-(triethylsilyl)paclitaxel (8) (9.5 mg) was mixed with $99 \%$ formic acid (Fluka, $0.15 \mathrm{~mL}$ ) and stirred for $30 \mathrm{~min}$ at room temperature. The formic acid was removed on a vacuum pump. The reaction mixture was diluted with EtOAc, and the solution was washed with $5 \% \mathrm{NaHCO}_{3}, \mathrm{H}_{2} \mathrm{O}$, and brine and dried. Solvents were removed by evaporation. 
Purification of the residue by PTLC (EtOAc/hexanes, 1:1) yielded paclitaxel (1) (2 mg, 28\%), identical with an authentic sample.

2,7-Di-O-(triethylsilyl)paclitaxel (11a). I midazole (136.0 $\mathrm{mg}, 2.0 \mathrm{mmol}$ ) and triethylsilyl chloride $(0.30 \mathrm{~mL}, 2.0 \mathrm{mmol})$ were sequentially added to a solution of paclitaxel (1) (170.6 $\mathrm{mg}, 0.2 \mathrm{mmol})$ in dry DMF $(1.0 \mathrm{~mL})$. The reaction mixture was stirred at room temperature for $2 \mathrm{~h}$ and diluted with EtOAc. The solution was washed successively with water (20 $\mathrm{mL} \times 2$ ) and brine. The organic layer was separated, dried over $\mathrm{Na}_{2} \mathrm{SO}_{4}$, and evaporated under reduced pressure to yield a transparent syrup. The crude material was chromatographed over silica gel using EtOAc/hexane (1:3) as el uent to obtain 2',7-di-O-(triethylsilyl)paclitaxel (11a) as a white solid (204 mg, 94\%). Mp: $122-124{ }^{\circ} \mathrm{C}$. ${ }^{1} \mathrm{H}$ NMR: $\delta 0.45(\mathrm{q}, \mathrm{J}=$ $7.8 \mathrm{~Hz}, 6 \mathrm{H}), 0.58(\mathrm{q}, \mathrm{J}=7.8 \mathrm{~Hz}, 6 \mathrm{H}), 0.81(\mathrm{t}, \mathrm{J}=7.8 \mathrm{~Hz}, 9 \mathrm{H})$, 0.90 (t, J = 7.8 Hz, 9H), 1.20 (s 3H), 1.25 (s 3H), 1.70 (s 3H), 2.05 (bs, 3H), 2.16 (s 3H), $2.32(\mathrm{~m}, 1 \mathrm{H}), 2.50(\mathrm{~m}, 1 \mathrm{H}), 2.54$ (s $3 \mathrm{H}), 3.83(\mathrm{~d}, \mathrm{~J}=7.0 \mathrm{~Hz}, 1 \mathrm{H}), 4.22(\mathrm{~d}, \mathrm{~J}=8.0 \mathrm{~Hz}, 1 \mathrm{H}), 4.32(\mathrm{~d}$, $J=8.0 \mathrm{~Hz}, 1 \mathrm{H}), 4.48(\mathrm{dd}, \mathrm{J}=10.6,6.6 \mathrm{~Hz}, 1 \mathrm{H}), 4.70(\mathrm{~d}, \mathrm{~J}=$ $2.1 \mathrm{~Hz}, 1 \mathrm{H}), 4.94(\mathrm{bd}, \mathrm{J}=8.8 \mathrm{~Hz}, 1 \mathrm{H}), 5.70(\mathrm{~m}, 2 \mathrm{H}), 6.24(\mathrm{bt}$, $1 \mathrm{H}), 6.45(\mathrm{~s} 1 \mathrm{H}), 7.10(\mathrm{~d}, \mathrm{~J}=8.9 \mathrm{~Hz}, 1 \mathrm{H}), 7.30-7.60(\mathrm{~m}, 11 \mathrm{H})$, $7.74(\mathrm{dd}, \mathrm{J}=8.5,1.1 \mathrm{~Hz}, 2 \mathrm{H}), 8.13(\mathrm{dd}, \mathrm{J}=8.5,1.4 \mathrm{~Hz}, 2 \mathrm{H})$. ${ }^{13} \mathrm{C}$ NMR: $\delta 4.34,5.28,6.49,6.72,10.10,14.15,20.85,21.46$, $23.05,26.53,35.55,37.21,43.31,46.64,55.68,58.39,71.41$, $72.19,74.40,74.92,74.96,76.55,76.68,76.99,77.31,78.82$, $81.15,84.22,126.45,127.01,127.91,128.65,128.71,129.20$, $130.19,131.71,133.58,133.65,134.05,138.41,140.16,166.90$, 167.28, 170.06, 171.55, 201.67. FABMS: $\mathrm{m} / \mathrm{z}[\mathrm{M}+\mathrm{Na}]^{+} 1104$ (100).

Reaction of 2,7-Di-O-(triethylsilyl)paclitaxel (11a) with NaOH/PTC: 2-Debenzoyl-2,7-di-O-(triethylsilyl)paclitaxel (12a). 2',7-Di-O-(triethylsilyl)paclitaxel (11a) $(216$ mg, 0.20 $\mathrm{mmol})$ was dissolved in benzene/ $\mathrm{CH}_{2} \mathrm{Cl}_{2}(8: 2,20 \mathrm{~mL})$. Tetrabutylammonium hydrogen sulfate $(800 \mathrm{mg}, 2.35 \mathrm{mmol})$ and $2 \mathrm{~N} \mathrm{NaOH}(20 \mathrm{~mL})$ were added sequentially. The mixture was stirred at room temperature, and the reaction was monitored by TLC. After $1 \mathrm{~h}$ TLC showed the presence of a new low $R_{f}$ spot (0.3) al ong with starting material $\left(R_{f} 0.75\right)$. After $2 \mathrm{~h}$ the reaction mixture was diluted with benzene $(25 \mathrm{~mL})$, and the solution was washed sequentially with water $(2 \times 25 \mathrm{~mL})$ and brine. The organic layer was separated, dried over $\mathrm{Na}_{2} \mathrm{SO}_{4}$, and evaporated. Purification by preparative TLC (silica gel, $1000 \mu \mathrm{m}$; hexane/EtOAc, 1:1) yielded 2-debenzoyl-2',7-di-O(triethylsilyl)paditaxel (12a) (70.0 mg, 35.8\%), 7-(triethylsilyl)baccatin (15.0 mg, 10\%), and starting material (110 mg, 51\%). ${ }^{1} \mathrm{H}$ NMR of 12a: $\delta 0.48(\mathrm{q}, \mathrm{J}=7.8 \mathrm{~Hz}, 6 \mathrm{H}), 0.58(\mathrm{q}, \mathrm{J}=7.8$ $\mathrm{Hz}, 6 \mathrm{H}), 0.81(\mathrm{t}, \mathrm{J}=7.8 \mathrm{~Hz}, 9 \mathrm{H}), 0.90(\mathrm{t}, \mathrm{J}=7.8 \mathrm{~Hz}, 9 \mathrm{H}), 1.05$ (s 3H), 1.10 (s 3H), 1.51 (s 3H), 1.95 (bs, 3H), 2.15 (s 3H), 2.40 (s $3 \mathrm{H}), 2.50(\mathrm{~m}, 1 \mathrm{H}), 3.25$ (bs, $1 \mathrm{H}), 3.49(\mathrm{~d}, \mathrm{~J}=6.8 \mathrm{~Hz}), 3.92$ $(\mathrm{t}, \mathrm{J}=5.8 \mathrm{~Hz}, 1 \mathrm{H}), 4.42(\mathrm{dd}, \mathrm{J}=10.6,6.7 \mathrm{~Hz}, 1 \mathrm{H}), 4.62$ (bs, $3 \mathrm{H}), 4.98(\mathrm{bd}, \mathrm{J}=8.8 \mathrm{~Hz}), 5.63(\mathrm{bd}, \mathrm{J}=9.5 \mathrm{~Hz}, 1 \mathrm{H}), 6.20(\mathrm{bt}$, $1 \mathrm{H}), 6.37(\mathrm{~s} 1 \mathrm{H}), 7.08(\mathrm{~d}, \mathrm{~J}=9.5 \mathrm{~Hz}, 1 \mathrm{H}), 7.15-7.50(\mathrm{~m}, 8 \mathrm{H})$, 7.78 (dd, J $=8.5,1.3 \mathrm{~Hz}, 2 \mathrm{H}$ ).

2-O-(tert-Butyldimethylsilyl)-7-O-(triethylsilyl)paclitaxel (11b). I midazole (107 mg, $1.58 \mathrm{mmol})$ and tert-butyldimethylsilyl chloride (238 $\mathrm{mg}, 1.58 \mathrm{mmol}$ ) were added to a stirred solution of paclitaxel $(270 \mathrm{mg}, 0.316 \mathrm{mmol})$ in 2.5 $\mathrm{mL}$ of anhydrous DMF. The solution was heated at $60^{\circ} \mathrm{C}$ for $2 \mathrm{~h}$. The mixture was cooled to room temperature, and imidazole (107 mg, $1.58 \mathrm{mmol}$ ) and triethylsilyl chloride (150 $\mu \mathrm{L}, 1.34 \mathrm{mmol}$ ) were added. After stirring at room temperature for $1 \mathrm{~h}$ the reaction mixture was diluted with EtOAc, and the solution was washed successively with $\mathrm{H}_{2} \mathrm{O}$ and brine. The organic layer was dried over $\mathrm{Na}_{2} \mathrm{SO}_{4}$, and evaporation of solvents under reduced pressure yielded crude material. Purification by column chromatography over silica gel (EtOAcl hexanes, 1:2) yielded 2'-O-(tert-butyldimethylsilyl)-7-O-(triethylsilyl)paclitaxel (11b) (325 mg, 95\%) as an amorphous solid. 'H NMR: $\delta-0.20$ (s 3H), -0.02 (s 3H), 0.62 (q, J $=7.8$ $\mathrm{Hz}, 6 \mathrm{H}), 0.79$ (s 9H), 0.92 (t, J $=7.8 \mathrm{~Hz}, 9 \mathrm{H}), 1.17$ (s 3H), 1.21 (s 3H), $1.70(\mathrm{~s} \mathrm{3H}), 1.88-1.92(\mathrm{~m}, 1 \mathrm{H}), 2.02$ (bs, 3H), 2.09-2.2 (m, $1 \mathrm{H}), 2.16(\mathrm{~s} 3 \mathrm{H}), 2.40(\mathrm{~m}, 1 \mathrm{H}), 2.55(\mathrm{~m}, 1 \mathrm{H}), 2.58(\mathrm{~s} 3 \mathrm{H})$, $3.83(\mathrm{~d}, \mathrm{~J}=7.0 \mathrm{~Hz}, 1 \mathrm{H}), 4.19(\mathrm{~d}, \mathrm{~J}=8.3 \mathrm{~Hz}, 1 \mathrm{H}), 4.30(\mathrm{~d}, \mathrm{~J}=$
$8.3 \mathrm{~Hz}, 1 \mathrm{H}), 4.48(\mathrm{dd}, \mathrm{J}=9.4,6.6 \mathrm{~Hz}, 1 \mathrm{H}), 4.67(\mathrm{~d}, \mathrm{~J}=2.1 \mathrm{~Hz}$, $1 \mathrm{H}), 4.94(\mathrm{bd}, \mathrm{J}=8.8 \mathrm{~Hz}, 1 \mathrm{H}), 5.69(\mathrm{~d}, \mathrm{~J}=7.0 \mathrm{~Hz}, 1 \mathrm{H}), 5.74$ $(\mathrm{dd}, \mathrm{J}=9.0,2.1 \mathrm{~Hz}, 1 \mathrm{H}), 6.26(\mathrm{bt}, 1 \mathrm{H}), 6.45(\mathrm{~s} 1 \mathrm{H}), 7.10(\mathrm{~d}, \mathrm{~J}$ $=8.9 \mathrm{~Hz}, 1 \mathrm{H}), 7.30-7.60(\mathrm{~m}, 11 \mathrm{H}), 7.74(\mathrm{dd}, \mathrm{J}=8.5,1.5 \mathrm{~Hz}$, $2 \mathrm{H}), 8.13(\mathrm{dd}, \mathrm{J}=8.5,1.4 \mathrm{~Hz}, 2 \mathrm{H}) .{ }^{13} \mathrm{C} N M R: \delta-5.86,-5.20$, 5.27, 6.73, 10.11, 14.24, 18.11, 20.85, 21.50, 23.10, 25.49, 26.54, $35.55,37.21,43.31,46.64,55.63,58.39,71.36,72.19,74.92$, 74.95, 75.10, 76.55, 78.82, 81.17, 84.22, 126.40, 126.97, 127.92, $128.68,128.70,128.71,129.19,130.20,131.76,133.60,133.66$, 134.03, 138.26, 140.14, 166.88, 167.03, 169.28, 170.13, 171.38, 201.67. FABMS: $m / z$ (rel int.) $[M+H]^{+} 1104$ (5), 705 (3), 422 (40), 354 (12), 105 (100). HRFABMS: m/z [M + Na $\mathrm{H}]^{+} 1104.4936\left(\mathrm{C}_{59} \mathrm{H}_{79} \mathrm{NO}_{14} \mathrm{Si}_{2} \mathrm{Na}\right.$ requires 1104.4937).

2-O-(tert-Butyldimethylsilyl)-2-debenzoyl-7-0-(triethylsilyl)paclitaxel (12b). Benzyltrimethylammonium hydroxide (100 $\mu \mathrm{L}, 40 \% \mathrm{w} / \mathrm{w}$ solution in methanol) was added to a solution of 2'-O-(tert-butyldi methylsilyl)-7-O-(triethyl silyl)paclitaxel (11b) (110.4 mg, $0.1 \mathrm{mmol}$ ) in anhydrous $\mathrm{CH}_{2} \mathrm{Cl}_{2}(5$ $\mathrm{mL}$ ) at $-78{ }^{\circ} \mathrm{C}$. The reaction mixture was stirred for $10 \mathrm{~min}$. The reaction flask was transferred to $\mathrm{a}-10^{\circ} \mathrm{C}$ bath (diethylene glycol, dry ice) and stirred for 10-15 min. During this time the progress of the reaction was monitored by TLC, which indicated the formation of a more polar compound. The mixture was diluted with cold $\mathrm{CH}_{2} \mathrm{Cl}_{2}\left(-78{ }^{\circ} \mathrm{C}, 10 \mathrm{~mL}\right)$ and quenched with $5 \mathrm{~mL}$ of $0.1 \mathrm{~N} \mathrm{HCl}$. The organic layer was removed, washed successively with water, dilute $\mathrm{NaHCO}_{3}$ solution, and brine, and dried over $\mathrm{Na}_{2} \mathrm{SO}_{4}$. Concentration under reduced pressure yielded crude residue, which was purified by PTLC (silica gel, $1000 \mu \mathrm{m}$; EtOAc/hexanes, 2:3) to yiel d 2'-O-(tert-butyl di methylsilyl)-2-debenzoyl-7-O-(triethylsilyl)paclitaxel (12b) $(73.0$ mg, 73\%; 81\% based on unrecovered starting material) and starting compound (11.0 mg, 10\%). $\mathrm{Mp}:{ }^{133}-135^{\circ} \mathrm{C}$. ${ }^{1} \mathrm{H}$ NMR: $\delta-0.28(\mathrm{~s} \mathrm{3H}),-0.04(\mathrm{~s} 3 \mathrm{H})$, $0.57(\mathrm{q}, \mathrm{J}=7.8 \mathrm{~Hz}, 6 \mathrm{H}), 0.80(\mathrm{~s} 9 \mathrm{H}), 0.92(\mathrm{t}, \mathrm{J}=7.8 \mathrm{~Hz}, 9 \mathrm{H})$, $1.07(\mathrm{~s} \mathrm{3H}), 1.15(\mathrm{~s} 3 \mathrm{H}), 1.60-1.62(\mathrm{~m}, 1 \mathrm{H}), 1.62(\mathrm{~s} \mathrm{3H}), 1.96$ (bs, 3H), 2.11-2.13 (m, 1H), 2.14 (s 3H), 2.40 (m, 1H), 2.42 (s $3 \mathrm{H}), 2.51(\mathrm{~m}, 1 \mathrm{H}), 2.64($ br s $1 \mathrm{H}), 2.79(\mathrm{~d}, \mathrm{~J}=5.9 \mathrm{~Hz}, 1 \mathrm{H})$, $3.46(\mathrm{~d}, \mathrm{~J}=7.0 \mathrm{~Hz}, 1 \mathrm{H}), 3.92(\mathrm{t}, \mathrm{J}=6.3 \mathrm{~Hz}, 1 \mathrm{H}), 4.41$ (dd, J $=9.4,6.6 \mathrm{~Hz}, 1 \mathrm{H}), 4.60(\mathrm{~d}, \mathrm{~J}=1.6 \mathrm{~Hz}, 1 \mathrm{H}), 4.63(\mathrm{bs}, 2 \mathrm{H}), 4.95$ $(\mathrm{bd}, \mathrm{J}=8.6 \mathrm{~Hz}, 1 \mathrm{H}), 5.67(\mathrm{dd}, \mathrm{J}=9.2,1.6 \mathrm{~Hz}, 1 \mathrm{H}), 6.24$ (bt, $1 \mathrm{H}), 6.37(\mathrm{~s} 1 \mathrm{H}), 7.05(\mathrm{~d}, \mathrm{~J}=9.2 \mathrm{~Hz}, 1 \mathrm{H}), 7.30-7.54(\mathrm{~m}, 8 \mathrm{H})$, 7.74 (dd, J $=8.3,1.5 \mathrm{~Hz}, 2 \mathrm{H}$ ). FABMS: $\mathrm{m} / \mathrm{z}$ (rel int.) $[\mathrm{M}+$ $\mathrm{Na}^{+} 1000$ (3), 400 (22), 354 (84), 105 (100). ${ }^{13} \mathrm{C}$ NMR: $\delta-5.75$, $-5.19,5.24,6.72,10.25,14.12,18.14,20.81,21,42,23.22,25.52$, $26.31,35.40,37.21,43.03,46.64,55.33,58.24,71.97,72.18$, $73.85,74.76,75.10,78.09,78.21,82.36,83.93,126.43,126.89$, $128.05,128.71,128.82,131.94,133.90,134.12,137.92,139.55$, $167.73,169.23,169.90,171.38,202.45$. HRFABMS: m/z [M $+\mathrm{Na}]^{+} 1000.4632\left(\mathrm{C}_{59} \mathrm{H}_{75} \mathrm{NO}_{14} \mathrm{Si}_{2} \mathrm{Na}\right.$ requires 1000.4624$)$

General Procedure for the Reaction of 2-Debenzoyl2,7-di-0-(triethylsilyl)paclitaxel (12a) with Carboxylic Acids. An appropriate carboxylic acid $(0.1 \mathrm{mmol})$ was dissolved in dry toluene $(0.2 \mathrm{~mL})$, and DCC (20.6 mg, $0.1 \mathrm{mmol})$ and PP ( $1.0 \mathrm{mg}, 0.006 \mathrm{mmol})$ were added to the solution. The mixture was stirred at room temperature for $5 \mathrm{~min}$, compound 12a $(10.0 \mathrm{mg}, 0.01 \mathrm{mmol})$ was added, and the reaction mixture was stirred at room temperature until the 12a was consumed (TLC analysis). The reaction mixture was diluted with EtOAc $(10 \mathrm{~mL})$ and filtered through a pad of silica gel and Celite, which was washed with additional EtOAc $(10 \mathrm{~mL})$. The EtOAc filtrate was concentrated on a rotary evaporator. Purification using preparative TLC (silica gel, $500 \mu \mathrm{m}$, hexane/EtOAc, 2:1) yiel ded 2-acyl-2-debenzoyl-2',7-di-O-(triethylsilyl)paclitaxels 13a (60-90\% yield).

General Procedure for the Reaction of 2'-0-(tertButyldimethylsilyl)-2-debenzoyl-7-O-(triethylsilyl)paclitaxel (12b) with Carboxylic Acids. An appropriate carboxylic acid $(0.1 \mathrm{mmol})$ in dry toluene $(0.2 \mathrm{~mL})$ was treated with DCC (20.6 mg, $0.1 \mathrm{mmol})$ and PP $(1.0 \mathrm{mg}, 0.006 \mathrm{mmol})$. The mixture was stirred at room temperature for $5 \mathrm{~min}$. Compound 12b (10.0 mg, $0.01 \mathrm{mmol}$ ) was added, and the reaction mixture was either stirred at room temperature or heated on an oil bath at $60{ }^{\circ} \mathrm{C}$ until the starting compound was consumed (TLC analysis, generally $4-16 \mathrm{~h}$ ). The reaction 
mixture was diluted with EtOAc $(10 \mathrm{~mL})$ and filtered through a pad of silica gel and Celite, which was washed with additional EtOAc $(10 \mathrm{~mL})$. The EtOAc filtrate was concentrated on a rotary evaporator. Purification using preparative TLC (silica gel, 500 m; hexane/EtOAc, 2:1) yielded 2-acyl-2'O-(tert-butyldimethylsilyl)-7-O-(triethylsilyl)paditaxels $\mathbf{1 3 b}$ (60$90 \%$ yield). Example: reaction of 3,5-dichlorobenzoic acid $(60.0$ $\mathrm{mg}, 0.31 \mathrm{mmol}, 10$ equiv), DCC (65 mg, $0.31 \mathrm{mmol}, 10$ equiv), and catalytic PP $(3.0 \mathrm{mg}$ ) with $\mathbf{1 2 b}(30 \mathrm{mg}, 0.03 \mathrm{mmol})$ in dry toluene $(0.4 \mathrm{~mL})$ at $60^{\circ} \mathrm{C}$ for $16 \mathrm{~h}$, followed by workup and isolation as described, yielded 2-(3,5-dichlorobenzoyl)-2-debenzoyl-2'-O-(tert-butyldimethylsilyl)-7-O-(triethyl silyl)paclitaxel $(27.0 \mathrm{mg}, 76 \%)$

Deprotection of Silyl Groups with Methanolic HCl. A 2-acyl-2-debenzoyl-2',7-di-O-(triethylsilyl)paclitaxel (13a) or a 2-acyl-2'-O-(tert-butyldimethylsilyl)-7-O-(triethylsilyl)paditaxel (13b) (0.005 mmol) was dissolved in freshly prepared methanolic $\mathrm{HCl}(5 \%, v / v)$ solution. The mixture was stirred at room temperature for 30-60 min and diluted with EtOAC $(10 \mathrm{~mL})$. The solution was washed successively with dilute $\mathrm{NaHCO}_{3}$ solution, $\mathrm{H}_{2} \mathrm{O}$, and brine. The organic layer was dried over $\mathrm{Na}_{2} \mathrm{SO}_{4}$ and concentrated to give crude product. Purification was carried out using preparative TLC to give homogeneous product in 70-90\% yield. Example: reaction of 2-debenzoyl-2-(3',5'-dichlorobenzoyl)-2'-O-(tert-butyldimethylsilyl)7-O-(triethylsilyl)paclitaxel $(25.0 \mathrm{mg})$ with freshly prepared methanolic $\mathrm{HCl}(10 \%, \mathrm{v} / \mathrm{v})$ at room temperature for $35 \mathrm{~min}$ as described gave 2-(3,5-dichlorobenzoyl)-2-debenzoylpaclitaxel (14dm) (17.2 mg, 86\%). ${ }^{1} \mathrm{H}$ NMR: $\delta, 1.13$ (s 3H), 1.23 (s 3H), $1.67(\mathrm{~s} 3 \mathrm{H}), 1.78(\mathrm{~s} 3 \mathrm{H}), 1.89(\mathrm{~m}, 1 \mathrm{H}), 2.28(\mathrm{~m}, 2 \mathrm{H}), 2.23(\mathrm{~s}$ $3 \mathrm{H}), 2.33$ (s $3 \mathrm{H}), 2.45(\mathrm{~d}, \mathrm{~J}=3.4 \mathrm{~Hz}, 1 \mathrm{H}), 2.57(\mathrm{~m}, 1 \mathrm{H}), 3.66$ (bs, $1 \mathrm{H}), 3.79(\mathrm{~d}, \mathrm{~J}=7.1 \mathrm{~Hz}, 1 \mathrm{H}), 4.14(\mathrm{~d}, \mathrm{~J}=8.2,1 \mathrm{H}), 4.40$ $(\mathrm{d}, \mathrm{J}=8.2 \mathrm{~Hz}, 1 \mathrm{H}), 4.43(\mathrm{bt}, 1 \mathrm{H}), 4.75(\mathrm{bs}, 1 \mathrm{H}), 4.96(\mathrm{~d}, \mathrm{~J}=$ $8.0 \mathrm{~Hz}, 1 \mathrm{H}), 5.58(\mathrm{~d}, \mathrm{~J}=7.1 \mathrm{~Hz}, 1 \mathrm{H}), 5.73(\mathrm{dd}, \mathrm{J}=9.2,1.6 \mathrm{~Hz}$, $1 \mathrm{H}), 6.17(\mathrm{bt}, 1 \mathrm{H}), 6.26(\mathrm{~s} 1 \mathrm{H}), 6.96(\mathrm{~d}, \mathrm{~J}=9.2 \mathrm{~Hz}, 1 \mathrm{H}), 7.30$ $7.74(\mathrm{~m}, 9 \mathrm{H}), 7.74(\mathrm{~d}, \mathrm{~J}=8.3 \mathrm{~Hz}, 2 \mathrm{H}) 8.00(\mathrm{~d}, \mathrm{~J}=1.7 \mathrm{~Hz}, 2 \mathrm{H})$. FABMS: $m / z$ (rel int.) $[\mathrm{M}+\mathrm{H}]^{+}$922. HRFABMS: $\mathrm{m} / \mathrm{z}[\mathrm{M}+$ $\mathrm{H}]^{+} 922.2592\left(\mathrm{C}_{47} \mathrm{H}_{50} \mathrm{NO}_{14} \mathrm{Cl}_{2}\right.$ requires 922.2608).

Synthesis of Compounds 14aa-eg. Compounds 14aaeg were prepared from paclitaxel by either the PTC method or the Triton B method described above, using the appropriate carboxylic acid in the acylation step. The final products were purified by PTLC, and product characterization was carried out by ${ }^{1} \mathrm{H}$ NMR spectroscopy, confirmed by HRMS in most cases. Structural assignment as the paclitaxel analogue $\mathbf{1 4}$ rather than an isopaclitaxel analogue such as $\mathbf{1 5}$ or a deprotected version was based on the signal for $\mathrm{H}-2$ at about 5.6$5.7 \mathrm{ppm}$; in the isopaclitaxel analogues this signal occurs at about $4.0 \mathrm{ppm}$. All products were at least $95 \%$ pure as indicated by their ${ }^{1} \mathrm{H}$ NMR spectra. Since the chemical shifts for most protons are essentially unchanged from those of paclitaxel, only the chemical shifts of those protons (AcO-4, $\mathrm{H}-2, \mathrm{H}-3$, and $\mathrm{H}_{2}-20$ ) which showed significant variations from compound to compound, together with the chemical shifts of the substituent protons, are listed. ${ }^{1} \mathrm{H}$ NMR and, in most cases, HRMS data for compounds 14aa-eg are summarized in Tables 3 and 4 in the Supporting Information.

Biological Assays. The assay for drug enhancement of tubulin polymerization was performed as described previously. ${ }^{16}$ Two series of experiments were performed, the first with $0.4 \mathrm{M}$ glutamate (all compounds) and the second with $0.8 \mathrm{M}$ glutamate (compounds less active than paclitaxel in the first experiment). Electrophoretically homogeneous bovine brain tubul in was prepared as described previously. ${ }^{24}$ Human Burkitt Iymphoma CA46 cells (a gift of Dr. Patrick O'Connor, National Cancer Institute) were grown in suspension culture as described previously. ${ }^{25}$ The ovarian carcinoma lines were as described previously. ${ }^{20,21}$ They were grown in monolayer cultures in microtiter plates, and I $\mathrm{C}_{50}$ values were determined as described by Skehan et al. ${ }^{26}$

Acknowledgment. We are grateful for the financial support for this work, which was provided by grants from the National Cancer Institute (CA 48974, CA
55131, and CA 69571) and from Bristol-Myers Squibb Pharmaceutical Research Institute (all to D.G.I.K.). We thank Dr. Kenneth Snader and the Natural Products Branch of the National Cancer Institute for a supply of partially purified extracts of $\mathrm{T}$. brevifolia that were used in the earlier stages of this work as sources of paclitaxel.

Supporting Information Available: Tables of bioactivity, ${ }^{1} \mathrm{H}$ NMR, and MS data (4 pages). Ordering information is given on any current masthead page.

\section{References}

(1) Wani, M. C.; Taylor, H. L.; Wall, M. E.; Coggon, P.; McPhail, A. T. Plant Antitumor Agents. VI. The I solation and Structure of Taxol, a Novel Antileukemic and Antitumor Agent from Taxus brevifolia. J . Am. Chem. Soc. 1971, 93, 2325-2327.

(2) (a) Schiff, P. B.; Fant, J .; Horwitz, S. B. Promotion of Microtubule Assembly in Vitro by Taxol. Nature 1979, 277, 665-667. (b) Manfredi, J . J .; Horwitz, S. B. Taxol: An Antimitotic Agent with a New Mechanism of Action. Pharmacol. Ther. 1984, 25, 83125.

(3) (a) Arbuck, S. G.; Blaylock, B. A. Taxol: Clinical Results and Current I ssues in Development. In Taxol: Science and Applications; Suffness, M., Ed.; CRC Press: Boca Raton, FL, 1995; pp 379-415. (b) Holmes, F. A.; Kudelka, A. P.; Kavanagh, J. . Huber, M. H.; Ajani, J . A.; Valero, V. Current Status of Clinical Trials with Paclitaxel and Docetaxel. In Taxane Anticancer Agents: Basic Science and Current Status; Georg, G. I., Chen, T. T., Ojima, I., Vyas, D. M., Eds.; ACS Symposium Series 583; American Chemical Society: Washington, DC, 1994; pp 31-57. (c) Donehower, R. C.; Rowinsky, E. K. An Overview of Experience with Taxol (Paclitaxel) in the U.S.A. Cancer. Treat. Rev. 1993 19 (Suppl.), 63-78. (d) Rowinsky, E. K.; Donehower, R. C. Paclitaxel (Taxol). N. Engl. J . Med. 1995, 1004-1014.

(4) (a) Chen, S.-H.; Farina, V. Paclitaxel Structure-Activity Relationships and Core Skeletal Rearrangements. In Taxane Anticancer Agents: Basic Science and Current Status; Georg, G. I., Chen, T. T., Ojima, I., Vyas, D. M., Eds.; ACS Symposium Series 583; American Chemical Society: Washington, DC, 1994; pp 247-261. (b) Georg, G. I.; Boge, T. C.; Cheruvallath, Z. S.; Clowers, J . S.; Harriman, G. C. B.; Hepperle, M.; Park, H. The Medicinal Chemistry of Taxol. In Taxol: Science and Applications; Suffness, M., Ed.; CRC Press: Boca Raton, FL, 1995; pp 317-375. (c) Kingston, D. G. I. The Chemistry of Taxol. Pharmacol. Ther. 1991, 52, 1-34. (d) Kingston, D. G. I. Taxol: the Chemistry and Structure-Activity Relationships of a Novel Anticancer Agent. Trends Biotechnol, 1994, 12, 222-227. (e) Kingston, D. G. I. Recent Advances in the Chemistry and Structure-Activity Relationships of Paclitaxel. In Taxane Anticancer Agents: Basic Science and Current Status; Georg, G. I., Chen. T. T., Ojima, I., Vyas, D. M., Eds.; ACS Symposium Series 583; American Chemical Society: Washington, DC, 1994; pp 203-216. (f) Kingston, D. G. I. History and Chemistry. In Paclitaxe in Cancer Treatment: McGuire, W. P., Rowinsky, E. K., Eds.; Marcel Dekker: New York, Basel, Hong Kong, 1995; Vol. 8, pp 1-33. (g) Nicolaou, K. C.; Dai, W.-M.; Guy, R. K. Chemistry and Biology of Taxol. Angew. Chem., Int. Ed. Engl. 1994, 33, 15-44.

(5) Samaranayake, G.; Magri, N. F.; J itrangsri, C.; Kingston, D. G. I. Modified Taxols. 5. Reaction of Taxol with Electrophilic Reagents and Preparation of a Rearranged Taxol Derivative with Tubulin Assembly Activity. J . Org. Chem. 1991, 56, 5114-5119.

(6) Neidigh, K. A.; Gharpure, M. M.; Rimoldi, J. M.; Kingston, D. G. I.; J iang, Y. Q.; Hamel, E. Synthesis and Biological Evaluation of 4-Deacetyl paditaxel. Tetrahedron Lett. 1994, 35, 6839-6842. (b) Chordia, M. D.; Chaudhary, A. G.; Kingston, D. G. I.; J iang, Y. Q.; Hamel, E. Synthesis and Biological Evaluation of 4-Deacetoxypaclitaxel. Tetrahedron Lett. 1994, 35, 6843-6846. (c) Datta, A.; J ayasinghe, L. R.; Georg, G. I. 4-Deacetyltaxol and 10-Acetyl-4-deacetyltaxotere: Synthesis and Biological Evaluation. J. Med. Chem. 1994, 37, 4258-4260.

(7) (a) Chen, S.-H: Kadow, J F. Farina, V: Fairchild, C. R J ohnston, K. A. First Syntheses of Novel Paclitaxel (Taxol) Analogues Modified at the C4-Position. J. Org. Chem. 1994, 59, 6156-6158. (b) Chen, S.-H.; Fairchild, C.; Long, B. H. Synthesis and Biological Evaluation of Novel C-4 Aziridine Bearing Paclitaxel (Taxol) Analogues. J . Med. Chem. 1995, 38, 2263-2267. (c) Chen, S.-H.; Wei, J .-M.; Long, B. H.; Fairchild, C. A.; Carboni, J .; Mamber, S. W.; Rose, W. C.; J ohnston, K. Casazza, A. M.; Kadow, J . F.; Farina, V.; Vyas, D.; Doyle, T. W. Novel C-4 Paclitaxel (Taxol) Analogues: Potent Antitumor Agents. Bioorg. Med. Chem. Lett. 1995, 5, 2741-2746. (d) Georg G. I.; Ali, S. M.; Boge, T. C.; Data, A.; Falborg, L.; Himes, R. H. Selective C-2 and C-4 Deacylation and Acylation of Taxol: The First Synthesis of a C-4 Substituted Taxol Analogue. Tetrahe dron Lett. 1994, 35, 8931-8934. 
(8) Chaudhary, A. G.; Gharpure, M. M.; Rimoldi, J . M.; Chordia, M. D.; Gunatilaka, A. A. L.; Kingston, D. G. I.; Grover, S.; Lin C. M.; Hamel, E. Unexpectedly Facile Hydrolysis of the 2-Benzoate Group of Taxol and Synthesis of Analogues with I ncreased Activities. J. Am. Chem. Soc. 1994, 116, 4097-4098.

(9) (a) Georg, G. I.; Harriman, G. C. B.; Ali, S. M.; Datta, A. Hepperle, M.; Himes, R. H. Synthesis of 2-O-Heteroaroyl Taxanes: Evaluation of Microtubule Assembly Promotion and Cytotoxicity. Bioorg. Med. Chem. Lett. 1995, 5, 115-118. (b) Georg, G. I.; Ali, S. M.; Boge, T. C.; Datta, A.; Falborg, L.; Park, H.; Mejillano, M.; Himes, R. H. Synthesis of Biologically Active 2-Benzoyl Paclitaxel Analogues. Bioorg. Med. Chem. Lett. 1995 5, 259-264. (c) Nicolaou, K. C.; Couladouros, E. A.; N antermet, P. G.; Renaud, J .; Guy, R. K.; Wrasidlo, W. Synthesis of C-2 Taxol Analogues, Angew. Chem., Int. Ed. Engl. 1994, 33, 15811583. (d) Nicolaou, K. C.; Renaud, J .; Nantermet, P. G.; Couladouros, E. A.; Guy, R. K.; Wrasidlo, W. Chemical Synthesis and Biological Evaluation of C-2 Taxoids. J . Am. Chem. Soc. 1995 117, 2409-2420. (e) Chen, S.; Farina, V.; Wei, J .; Long, B. Fairchild, C.; Mamber, S. W.; Kadow, J. F.; Vyas, D.; Doyle, T. W. Structure-Activity Relationships of Taxol: Synthesis and Biological Evaluation of C-2 Taxol Analogues. Bioorg. Med. Chem. Lett. 1994, 4, 479-482. (f) Grover, S.; Rimoldi, J. M.; Molinero, A. A.: Chaudhary, A. G.; Kingston, D. G. I.; Hamel, E. Differential Effects of Paclitaxel (Taxol) Analogues Modified at Positions C-2, C-7, and C-3' on Tubulin Polymerization and Polymer Stabilization: I dentification of a Hyperactive Paclitaxe Derivative. Biochemistry 1995, 34, 3927-3934. (g) Ojima, I.; Duclos, O.; Zucco, M.; Lavelle, F. Synthesis and StructureActivity Relationships of New Antitumor Taxoids. Effects of Cyclohexyl Substitution at the C-3' and/or C-2 of Taxotere (Docetaxel). J . Med. Chem. 1994, 37, 2602-2608. (h) Holton, R. A.; Kim, S. Process for the Preparation of Baccatin III Analogues Bearing New C-2 and C-4 Functional Groups. U.S. Patent 5,399,726, March 21, 1995. (i) Ojima, I.; Kuduk, S. D.; Pera, P. Veith, J . M.; Bernacki, R. J . Syntheses and Structure-Activity Relationships of Nonaromatic Taxoids: Effects of Alkyl and Alkenyl Ester Groups on Cytotoxicity. J . Med. Chem. 1997, 40, 279-285.

(10) (a) Vander Velde, D. G.; Georg, G. I.; Grunewald, G. L.; Gunn, C. W.; Mitscher, L. A. "Hydrophobic Collapse" of Taxol and Taxotere Solution Conformations in Mixtures of Water and Organic Solvent. J . Am. Chem. Soc. 1993, 115, 11650-11651. (b) Williams, H. J .; Scott, A. I.; Dieden, R. A.; Swindell, C. S.; Chirlian, L. E.; Frand, M. M.; Heerding, J. M.; Krauss, N. E NMR and Molecular Modeling Study of Active and Inactive Taxo Analogues in Aqueous and Nonaqueous Solution. Can. J . Chem 1994, 72, 252-260. (c) Ojima, I.; Kuduk, S. D.; Chakravarty, S.; Ourevitch, M.; Bégué, J.-P. A Novel Approach to the Study of Solution Structures and Dynamic Behavior of Paditaxel and Docetaxel Using Fluorine-Containing Analogues as Probes. J . Am. Chem. Soc. 1997, 119, 5519-5527.

(11) Miller, R. W.; Powell, R. G.; Smith, C. R., J r.; Arnold, E.; Clardy, J . Antileukemic Alkaloids from Taxus wallichiana Zucc. J . Org. Chem. 1981, 46, 1469-1474.

(12) Samaranayake, G.; Neidigh, K. A.; Kingston, D. G. I. Modified Taxols. 8. Deacylation and Reacylation of Baccatin III. J . Nat. Prod. 1993, 56, 884-898.

(13) Flynn, D. L.; Zelle, R. E.; Grieco, P. A. A Mild Two-Step Method for the Hydrolysis/M ethanolysis of Secondary Amides and Lactams. J . Org. Chem. 1983, 48, 2424-2426.

(14) Farina, V.; Huang, S. The Chemistry of Taxanes: Unexpected Rearrangement of Baccatin III During Chemoselective Debenzoylation with Bu3SnOMe/LiCl. Tetrahedron Lett. 1992, 33, 3979-3982.

(15) (a) Denis, J .-N.; Greene, A. E.; Guenard, D.; Gueritte-Voegelein, F.; Mangatal, L.; Potier, P. A Highly Efficient, Practical Approach, to Natural Taxol. J . Am. Chem. Soc. 1988, 110, 5917-
5919. (b) Ojima, I.; Habus, I.; Zhao, M.; Zucco, M.; Park, Y. H.; Sun, C. M.; Brigaud, T. New and efficient approaches to the semisynthesis of taxol and its C-13 side chain analogues by means of $\beta$-lactam synthon method. Tetrahedron 1992, 48, 6985-7012. (c) Holton, R. A.; Biediger, R. J .; Boatman, P. D. Semisynthesis of Taxol and Taxotere. In Taxol: Science and Applications; Suffness, M., Ed.; CRC Press: Boca Raton, FL, 1995; pp 97-121.

(16) Lin, C. M.; J iang, Y. Q.; Chaudhary, A. G.; Rimoldi, J. M.; Kingston, D. G. I.; Hamel, E. A Convenient Tubulin-Based Quantitative Assay for Paclitaxel (Taxol) Derivatives More Effective in Inducing Assembly than the Parent Compound. Cancer Chemother. Pharmacol. 1996, 38, 136-140.

(17) $I C_{50}$ is enclosed in quotation marks at its first appearance because taxoids actually enhance tubulin polymerization. In the assay used here, the drug concentration required to reduce the protein in the supernatant by $50 \%$ was determined, since the drug-induced polymer is removed from the reaction mixture by centrifugation.

(18) Hamel, E.; del Campo, A. A.; Lowe, M. C.; Lin, C. M. Interactions of Taxol, Microtubule-Associated Proteins, and Guanine Nucleotides in Tubulin Polymerization. J. Biol. Chem. 1981, 256, 11887-11894.

(19) Rimoldi, J . M.; Kingston, D. G. I.; Chaudhary, A. K.; Samaranayake, G.; Grover, S.; Hamel, E. Modified Taxols, 9. Synthesis and Biological Evaluation of 7-Substituted Photoaffinity Analogues of Taxol. J . Nat. Prod. 1993, 56, 1313-1330.

(20) Behrens, B. C.; Hamilton, T. C.; Masuda, H.; Grotzinger, K. R.; Whang-Peng, J .; Louie, K. G.; Knutsen, T.; McKoy, W. M.; Young, R. C.; Ozols, R. F. Characterization of a cis-Diaminedichloroplatinum(II)-Resistant Human Ovarian Cancer Cell Line and Its Use in Evaluation of Platinum Analogues. Cancer Res. 1987, 47, 414-418.

(21) Giannakakou, P.; Sackett, D. L.; Kang, Y.-K.; Zhan, Z.; Buters, J . T. M.; Fojo, T.; Poruchynsky, M. S. Paclitaxel resistant human ovarian cancer cells have mutant $\beta$-tubulins that exhibit impaired paclitaxel driven polymerization. J . Biol. Chem. 1997, 272, 17118-17125.

(22) Hansch, C.; Leo, A.; Unger, S. H.; Kim, K. H.; Nikaitani, D.; Lien, E. J. "Aromatic" Substituent Constants for StructureActivity Correlations. J . Med. Chem. 1973, 16, 1207-1216.

(23) The reader is reminded that only differences in $I C_{50}$ values greater than $20 \%$ are considered significant.

(24) Hamel, E.; Lin, C. M. Separation of Active Tubulin and Microtubule-Associated Proteins by UItracentrifugation and I solation of a Component Causing the Formation of Microtubule Bundles. Biochemistry 1984, 23, 4173-4184.

(25) ter Haar, E.; Kowalski, R. J .; Hamel, E.; Lin, C. M.; Longley, R. E.; Gunasekera, S. P.; Rosenkranz, H. S.; Day, B. W. Discodermolide, a Cytotoxic Marine Agent that Stabilizes Microtubules More Potently than Taxol. Biochemistry 1996, 35, 243-250.

(26) Skehan, P.; Storeng, R.; Scudiero, D.; Monks, A.; McMahon, J .; Vistica, D.; Warren, J . T.; Bokesch, H.; Kenney, S.; Boyd, M. R. New Colorimetric Cytotoxicity Assay for Anticancer-Drug Screening. J . Natl. Cancer Inst. 1990, 82, 1107-1112.

(27) Williams, R. C., J r.; Lee, J . C. Preparation of tubulin from Brain. Methods Enzymol. 1982, 85, 376-385.

(28) Swindell, C. S.; Krauss, N. E.; Horwitz, S. B.; Ringel, I. Biologically Active Taxol Analogues with Deleted A-Ring Side Chain Substituents and Variable C-2' Configurations. J . Med. Chem. 1991, 34, 1176-1184.

\section{J M 980229D}

